\title{
Deregulated expression of cytoskeleton related genes in the spinal cord and sciatic nerve of presymptomatic SOD1G93A Amyotrophic Lateral Sclerosis mouse model
}

\author{
Jessica R. Maximino, Gabriela P. de Oliveira, Chrystian J. Alves and Gerson Chadi*
}

Department of Neurology, Neuroregeneration Research Center, University of São Paulo School of Medicine, São Paulo, Brazil

Edited by:

Dirk M. Hermann, University

Hospital Essen, Germany

\section{Reviewed by:}

Ulkan Kilic, Bezmialem Vakif

University, Turkey

Carolina Hoyo-Becerra, University

Hospital Essen, Germany

\section{*Correspondence:}

Gerson Chadi, Department of Neurology, University of São Paulo, Av. Dr. Arnaldo, 455, 2nd floor, room 2119, São Paulo 01246-903, Brazil e-mail: gerchadi@usp.br
Early molecular events related to cytoskeleton are poorly described in Amyotrophic Lateral Sclerosis (ALS), especially in the Schwann cell (SC), which offers strong trophic support to motor neurons. Database for Annotation, Visualization and Integrated Discovery (DAVID) tool identified cytoskeleton-related genes by employing the Cellular Component Ontology (CCO) in a large gene profiling of lumbar spinal cord and sciatic nerve of presymptomatic $\mathrm{SOD} 1^{\mathrm{G} 93 \mathrm{~A}}$ mice. One and five $\mathrm{CCO}$ terms related to cytoskeleton were described from the spinal cord deregulated genes of 40 days (actin cytoskeleton) and 80 days (microtubule cytoskeleton, cytoskeleton part, actin cytoskeleton, neurofilament cytoskeleton, and cytoskeleton) old transgene mice, respectively. Also, four terms were depicted from the deregulated genes of sciatic nerve of 60 days old transgenes (actin cytoskeleton, cytoskeleton part, microtubule cytoskeleton and cytoskeleton). Kif1b was the unique deregulated gene in more than one studied region or presymptomatic age. The expression of Kif1b [quantitative polymerase chain reaction (qPCR)] elevated in the lumbar spinal cord ( 40 days old) and decreased in the sciatic nerve (60 days old) of presymptomatic ALS mice, results that were in line to microarray findings. Upregulation ( 24.8 fold) of Kif $1 \mathrm{~b}$ was seen in laser microdissected enriched immunolabeled motor neurons from the spinal cord of 40 days old presymptomatic SOD1 ${ }^{\mathrm{G} 93 \mathrm{~A}}$ mice. Furthermore, Kif $1 \mathrm{~b}$ was dowregulated in the sciatic nerve Schwann cells of presymptomatic ALS mice (60 days old) that were enriched by means of cell microdissection (6.35 fold), cell sorting (3.53 fold), and primary culture ( 2.70 fold) technologies. The gene regulation of cytoskeleton molecules is an important occurrence in motor neurons and Schwann cells in presymptomatic stages of ALS and may be relevant in the dying back mechanisms of neuronal death. Furthermore, a differential regulation of Kif1b in the spinal cord and sciatic nerve cells emerged as key event in ALS.

Keywords: ALS, SOD1 ${ }^{\text {G93A }}$, pre-symptomatic, spinal cord, sciatic nerve, Kif1b microarray

\section{INTRODUCTION}

Amyotrophic Lateral Sclerosis (ALS) is a progressive, rapid and fatal neurodegenerative disease that affects motor neurons of the spinal cord, brainstem, and cerebral cortex (Tripathi and AlChalabi, 2008). The mortality is often due to a respiratory failure (Shaw et al., 2001).

ALS pathogenesis is still unknown. Nevertheless, the mechanisms underlying neurodegeneration in ALS seem multifactorial and take place in neurons and non-neuronal cells (Boillee et al., 2006a,b; Yamanaka et al., 2008; Wang et al., 2013). Recent analyses have showed the involvement of cytoskeleton, leading a disruption of intracellular function, and intercellular communication, with relevance to the triggering of motor neuron death (Guipponi et al., 2010). In fact, those events are especially important to motor neurons, highly polarized cells that establish contact with their target and surrounding Schwann cells through long axons.

The steady bidirectional flux of molecules and organelles in the motor neuron axons is necessary for cell survival and maintenance (Liu et al., 2013; Vinsant et al., 2013). In this context, cytoskeleton impairments might account for the described ALS mechanisms as regarding axonal/mitochondrial alteration, signaling endosome dysfunction, protein aggregation and apoptosis (Boillee et al., 2006a,b; Ferraiuolo et al., 2011; Kiernan et al., 2011; Usuki et al., 2012).

The presence of Schwann cell-expressing the distress biomarker ATF-3 in spinal nerves (Malaspina et al., 2010) before symptom onset suggests the contribution of those cells to ALS pathogenesis (Keller et al., 2009). Remarkably, axonal retraction and motor neuron disconnection from neuromuscular joints are ALS early events (Fischer et al., 2004; Parkhouse et al., 2008) that seem to be induced by Schwann cell mechanisms (Vinsant et al., 2013). For instance, distal Schwann cells produce semaphorin 3, a chemorepellent molecule for terminal axons (De Winter et al., 2006). Furthermore, the expression of the glial intermediate filament protein GFAP in Schwann cells of the peripheral nerve implies a dynamic alteration of cytoskeleton and turnover of myelin sheath (Hanyu et al., 1982). Moreover, an accumulation of iNOS immunoreactivity at the paranodal regions of Schwann cell myelin sheaths of peripheral nerves of presymptomatic ALS mice gives additional evidence for the impaired paracrine mechanisms 
between motor neuron and Schwann cell (Chen et al., 2010). Thus, it should be considered that the early peripheral events related to cytoskeleton of motor neurons and Schwann cells may contribute to neuronal dying back via disruption of peripheral neurotrophic stimuli (Keller et al., 2009; Dadon-Nachum et al., 2011; Gould and Kendall, 2011; Gould and Oppenheim, 2011; Liu et al., 2013).

As a short lasting disease, the challenge on ALS investigation is the employment of an adequate experimental model to evaluate presymptomatic mechanisms triggering motor neuron death. With this regard, it is known that transgene mice expressing human mutant copper/zinc superoxide dismutase 1 (SOD1 ${ }^{\text {G93A }}$ ) develop clinical and pathological features similar to those seen in human ALS and are considered an excellent model to study the pathogenic mechanisms of the disease (Gama Sosa et al., 2012). The model is particularly useful to evaluate the events related to motor neuron degeneration prior neurological symptoms (Alves et al., 2011).

Large-scale microarray-based gene expression has been trying to identify new molecular cues potentially involved in the ALS pathogenesis both in animal models and postmortem tissue (Olsen et al., 2001; Hensley et al., 2002; Yoshihara et al., 2002; Dangond et al., 2004; Perrin et al., 2005; Ferraiuolo et al., 2007, 2009; Fukada et al., 2007; Lobsiger et al., 2007; Vargas et al., 2008; Kudo et al., 2010; Boutahar et al., 2011; Cooper-Knock et al., 2012). However, there is a lack of investigation on the analysis of cytoskeleton-related gene profiling. The evaluation of deregulated genes in specific enriched cells obtained by in vitro purification, single cell laser microdissection or cell sorting might contribute to refine the alterations of gene expression-related to cytoskeleton molecules on specific cells of peripheral motor neuron unit.

By means of a high-density oligonucleotide microarray-linked to specific tools capable to identify cellular components, the aim of this work was to identify the regulation of cytoskeleton-related genes in the presymptomatic stage in the spinal cord and sciatic nerve of the SOD1 ${ }^{\mathrm{G} 93 \mathrm{~A}}$ mouse model. The work has also evaluated the modulation of Kif $1 b$ in the enriched spinal cord motor neurons and sciatic nerve Schwann cells.

\section{MATERIALS AND METHODS ANIMAL AND TISSUE SAMPLE}

Transgene SOD1 ${ }^{\text {G93A }}$ mice (The Jackson Laboratory, Bar Harbor, ME, USA) were crossbred and the colony was maintained in a specific pathogen-free environment of the animal facility of University of São Paulo Medical School (São Paulo, Brazil) as described previously (Gurney, 1994; Scorisa et al., 2010; Alves et al., 2011). Animals were kept under controlled temperature and humidity conditions with a standardized light-dark cycle (lights on at 7.00 a.m. and off at 7.00 p.m.) and free access to food pellets and tap water. Mice were genotyped by PCR amplification of DNA extracted from their tails in order to identify the SOD1 mutation (Gurney, 1994; Scorisa et al., 2010; Alves et al., 2011). The study was conducted under protocols approved by the Animal Care and Use of Ethic Committee at University of São Paulo and in accordance to the Guide for the Care and Use of Laboratory Animals adopted by the National Institutes of Health.
Forty, 60, and 80 days old presymptomatic specific pathogenfree male SOD ${ }^{\mathrm{G} 93 \mathrm{~A}}$ mice and their age-paired wild-type controls (20-25 g body weight) were used in the experiments. No motor neuron death was seen in those animal ages (Alves et al., 2011) so that they were chosen for the present presymptomatic analyses. Animals were killed by decapitation. Lumbar spinal cords (40 and 80 days old mice) and sciatic nerves (60 days old mice) were removed, frozen, and stored at $-80^{\circ} \mathrm{C}$ until use. Four-five animals per group were used in the microarray experiments. The quantitative polymerase chain reaction (qPCR) analyses of lumbar spinal cords (40 days old mice), and sciatic nerves (60 days old mice) as well as of enriched cells samples (60 days old mice) employed four mice of each transgene and wild-type groups.

\section{RNA ISOLATION AND MICROARRAY EXPERIMENTS}

The procedures of microarray experiments and statistical analysis of the mouse spinal cords were described in our previous publication which has employed a Whole Mouse Genome Oligo $4 \times 44 \mathrm{~K}$ microarray platform (Agilent Technologies, USA) (De Oliveira et al., 2013). Regarding the sciatic nerve samples, total RNA was isolated using the Miniprep kit (Zymo, USA). The procedure was performed according to the manufacturer's instructions. The quantity and integrity of RNA were determined by spectrophotometer (Nanodrop, Thermo Scientific, USA) and microfluidics-based electrophoresis (Agilent 2100 Bioanalyzer, Agilent Technologies, USA), respectively. RNA samples with OD 260/280 of approximately 2.0 and RIN $>7.0$ were used for microarray experiments and qPCR. A pool of RNAs from neonatal organs (heart, kidney, liver) was used as reference sample. A representative electropherogram from Bioanalyzer evaluation of RNA integrity of the sciatic nerve samples is shown in the supplementary material (Figure S1).

In the case of sciatic nerve analysis, RNAs of samples ( $25 \mathrm{ng}$ ) and reference ( $100 \mathrm{ng}$ ) were reverse transcribed by the Low-input RNA Linear Amplification kit and then transcribed to Cy3labelled (samples) or Cy5-labelled (reference) according to the manufacturer's instructions (Agilent Technologies, USA) and to previous descriptions (De Oliveira et al., 2013, 2014).

A total of 300 ng of Cy3-labelled cRNA was hybridized together with the same amount of Cy5-labelled reference to Whole Mouse Genome Oligo $8 \times 60 \mathrm{~K}$. After an overnight hybridization at $65^{\circ} \mathrm{C}$, the slides were washed and treated with a Stabilizing and Drying Solution (Agilent Technologies, USA) and scanned (Agilent Microarray Scanner). All steps were performed according to the manufacturer's instructions (Agilent Technologies, USA).

The raw data from hybridizations and experimental conditions are available on the Gene Expression Omnibus website under accession numbers GSE50642 (spinal cord analysis, according to De Oliveira et al., 2013) and GSE56926 (sciatic nerve analysis).

\section{MICROARRAY ANALYSIS}

Raw image data were converted to numerical data using the Agilent Feature Extraction Software, version 9.1.3.1 (spinal cord) (De Oliveira et al., 2013) and version 11.0.1.1 (sciatic nerve).

Microarrays without enough quality were taken out from further analyses, and the study proceeded with four samples for each group in the both studied regions. As already described for spinal 
cord in our previous study (De Oliveira et al., 2013), sciatic nerve microarray raw data (.txt files) were transferred to R v. 3.0.1 software (Team RDC, 2012) and analyzed with the Bioconductor (Gentleman et al., 2004) package limma (Smyth, 2005). Finally, the probes were tested for differential expression using a linear model followed by Bayes moderated t-test (Smyth, 2005) for the comparisons of interest. $P$-values $<0.05$ were accepted as differentially expressed genes.

\section{COMPLEMENTARY DNA MICROARRAY DATA ANALYSIS}

The Database for Annotation, Visualization and Integrated Discovery (DAVID) v6.7b functional tool (http://david.abcc. ncifcrf.gov/) (Huang Da et al., 2008) was used to identify genes related to cytoskeleton through the Gene Ontology (GO) annotation database. DAVID analysis focused in the Cellular Component Ontology (CCO). The analysis was conducted on the lists containing the up-regulated and down-regulated genes for each experimental group. High stringency (EASE score set to 0.05) parameters were selected to improve confidence on the terms to be pointed as enriched. Cellular component terms related to cytoskeleton gene lists were then organized. The BioVenn tool (http://www.cmbi.ru.nl/cdd/biovenn/) (Hulsen et al., 2008) was used to identify common and exclusively expressed genes between groups.

\section{LASER CAPTURE MICRODISSECTION OF MOTOR NEURONS FROM SPINAL CORD}

Immunolabeled motor neurons of lumbar mouse spinal cord (SOD1 ${ }^{\mathrm{G} 93 \mathrm{~A}}$ and wild-type groups) were microdissected as described previously (De Oliveira et al., 2009, 2013). Spinal cord sections were rinsed for $3 \mathrm{~min}$ in phosphate buffered saline (PBS) containing 3\% Triton X-100 (Sigma, USA) and then incubated overnight with a polyclonal goat anti-choline acetyltransferase (ChAT, 1:100; Abcam, USA) diluted in 0.3\% Triton X-100 containing $1 \%$ bovine serum albumin (BSA; Sigma, USA), $1 \mathrm{mM}$ dithiothreitol (DTT; Invitrogen, CAN), and $0.1 \mathrm{U} / \mu \mathrm{l}$ RNAse inhibitor (Invitrogen, CAN). Sections were then washed in PBS $(3 \times 15 \mathrm{~s})$ and then incubated for $1 \mathrm{~h}$ in the dark and at room temperature with an Alexa 594-conjugated donkey anti-goat antibody (Invitrogen, USA) diluted (1:100) in the solution described above. Sections were rinsed carefully three times with PBS for $15 \mathrm{~s}$ and immediately submitted to single cell laser microdissection procedures. The ChAT immunofluorescence profiles for specific identification of motor neurons in the microdissection procedure are illustrated in Figures 1A,B.

About 100 motor neurons were isolated from each lumbar spinal cord using P.A.L.M. Microlaser Technologies (Zeiss). RNA was extracted from the microdissected motor neurons using the PicoPure RNA isolation kit (Arcturus, USA). Linear amplification of RNA was performed following Eberwine's procedure (Van Gelder et al., 1990) using the RiboampHSplus kit (Arcturus, USA) according to the manufacturer's protocol. The quantity and quality of the amplified RNA were analyzed as described above. Laser microdissected motor neuron samples were submitted to PCRs for verification of sample enrichment and the results are shown in the supplementary material (Figure S2).
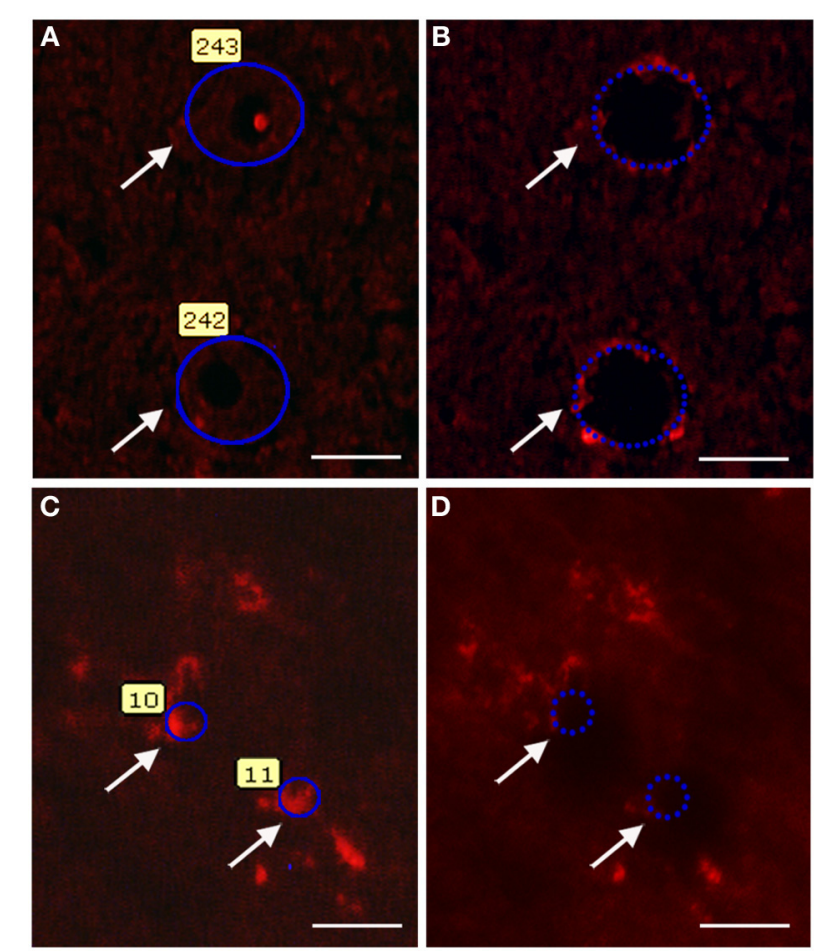

FIGURE 1 | Photomicrographs illustrating motor neuron (A,B) and Schwann cell $(C, D)$ laser microdissection process. The quick ChAT and $\mathrm{S} 100 \beta$ immunofluorescence procedures allow recognizing the motor neuron (A,B) and Schwann cell (C,D) profiles (arrows). Profiles were then selected for microdissection $(\mathbf{A}, \mathbf{C})$. After laser firing and microdissection, selected cell profiles (arrows) can no longer be visualized in the tissue (B,D). Scale bars: $20 \mu \mathrm{m}$.

\section{LASER CAPTURE MICRODISSECTION OF SCHWANN CELLS FROM SCIATIC NERVE}

Sciatic nerve of 60 days old mice (SOD1 ${ }^{\mathrm{G} 93 \mathrm{~A}}$ and wild-type groups) were rapidly removed and frozen in ice cold isopentane at $-45^{\circ} \mathrm{C}$ and stored at $-80^{\circ} \mathrm{C}$ until use. The labeling procedure was performed according to adaptation of a previous description (De Oliveira et al., 2009, 2013). Taw-mounted mouse sciatic nerve sections $(5 \mu \mathrm{m})$ were rapidly defrosted for $30 \mathrm{~s}$ and fixed with ice-cold acetone, for $3 \mathrm{~min}$. Sections were then rinsed $(3 \mathrm{~min}$ ) in PBS containing 3\% Triton X-100 and incubated with a polyclonal rabbit anti-S100 $\beta$ antibody (1:200; Dako, USA) diluted in PBS containing $0.3 \%$ Triton X-100 (Sigma, USA) and 1\% BSA (Sigma, USA) for $5 \mathrm{~min}$. Sections were washed in PBS $(3 \times 15 \mathrm{~s})$ and then incubated $(5 \mathrm{~min})$ in the dark and at room temperature with a texas red-conjugated goat anti-rabbit antibody (Jackson ImmunoResearch Laboratories, USA) diluted (1:50) in the solution described above. Sections were then rinsed carefully three times with PBS for $15 \mathrm{~s}$ and immediately submitted to single cell laser microdissection procedures. Schwann cell S100 $\beta$ immunofluorescence profiles identified in the microdissection procedure are illustrated in Figures 1C,D.

About 200 Schwann cells were isolated from each sciatic nerve using the P.A.L.M. Microlaser Technologies. The RNA was extracted from the cells and amplified as described above. 
The quantity and quality of amplified RNA were analyzed as described above. Laser microdissected Schwann cell profiles were also submitted to PCRs for verification of sample enrichment. The detailed protocol and results are shown in the supplementary material (Figure S3).

\section{FLOW CYTOMETRY SORTING SCHWANN CELLS}

Schwann cells were isolated by means of flow cytometry sorting from the sciatic nerve explants of 60 days old SOD $1^{\mathrm{G} 93 \mathrm{~A}}$ mice and their age-paired wild-type controls. Briefly, animals were deeply anaesthetized with sodium pentobarbital $3 \%(100 \mathrm{mg} / \mathrm{kg}$, ip) and their sciatic nerves were dissected under aseptic conditions. Nerves were then placed in $60 \mathrm{~mm}$ dishes containing Leibovitz-15 medium (Gibco, USA), divested of their epineurial sheaths and chopped into $1 \mathrm{~mm}$ pieces. The fragments were then transferred to new $60 \mathrm{~mm}$ dishes containing D-10 culture medium [composed by DMEM (Gibco, USA) supplemented with $10 \%$ fetal bovine serum and $1 \%$ penicillin/streptomycin (Sigma, USA)] and were maintained there in $5 \% \mathrm{CO}_{2}$ at $37^{\circ} \mathrm{C}$ for 5 days. The sciatic nerve fragments were then transferred to $30 \mathrm{~mm}$ dishes containing $2.5 \mathrm{ml}$ Hanks' Balanced Salt solution (Sigma, USA), $0.05 \%$ trypsin (Gibco, USA), and $1 \mathrm{mg}$ collagenase (Worthington, USA). The fragments were kept in that solution for $2 \mathrm{~h}$ in $5 \% \mathrm{CO}_{2}$ at $37^{\circ} \mathrm{C}$. Tissue fragments were washed with D-10 and dissociated by trituration through a $200 \mu \mathrm{l}$-pipette and a 19-gauge sterile needle. The suspension was centrifuged at $1500 \mathrm{rpm}$ for $5 \mathrm{~min}$ at $4^{\circ} \mathrm{C}$ and the cells were resuspended in D-10 medium. This step was repeated and cells were passed through a $70 \mu \mathrm{m}$-cell strainer (BD Bioscience, USA).

The cells were centrifuged at $1,500 \mathrm{rpm}$ for $5 \mathrm{~min}$ at $4^{\circ} \mathrm{C}$ and the pellets were resuspended in PBS containing $10 \%$ fetal bovine serum and $0.01 \%$ sodium azide, (Sigma, USA). Sciatic nerve-derived cell suspension was incubated with a fluorescein isothiocyanate (FITC)-conjugated mouse p75NGF receptor antibody (Abcam, USA) diluted in the buffer solution (1/200) for $1 \mathrm{~h}$ at room temperature as mentioned above. The p75NGF receptor labeling was employed in the cell sorting experiments because it is a well-characterized surface marker for Schwann cells (Niapour et al., 2010). The samples were then centrifuged $\left(300 \times \mathrm{g}\right.$ for $5 \mathrm{~min}$ at $\left.4^{\circ} \mathrm{C}\right)$. The pellets were washed two times and resuspended in the PBS described above $(500 \mu \mathrm{l})$. Cells were then analyzed for type and specificity as well as separated on a FACSAria III Cell Sorter (BD Biosciences, USA). A maximum of $10^{6}$ cells were resuspended in $500 \mu \mathrm{l}$ of buffer. Flow cytometry dot plot Schwann cell profiles are shown in Figure 2. Details of flow cytometry procedures for cell specificity are described in the supplementary material (Figure S4).

RNA of enriched cells was extracted using Trizol (Life Technologies, USA) according to the manufacturer's protocol. The quantity (NanoDrop 1000 Spectrophotometer) and quality (Agilent 2100 bioanalyser, RNA 6000 Pico LabChip) of RNA were analyzed as described above. Also, the Schwann cell samples were submitted to PCRs in order to access contamination from other cell types. Protocol and results regarding specificity of separated Schwann cell samples are presented in the supplementary material (Figures S3).

\section{PRIMARY SCHWANN CELL CULTURE}

Highly purified Schwann cell cultures were obtained from sciatic nerve explants taken from 60 days old SOD $1{ }^{\mathrm{G} 93 \mathrm{~A}}$ and wild-type mice as described above. Nerve pieces were transferred weekly to new $60 \mathrm{~mm}$ dishes filled with $1 \mathrm{ml}$ of D-10 for 5 weeks. Dishes were replaced every other day with a fresh medium (Oudega et al., 1997). After that period, explants were replated onto $35 \mathrm{~mm}$ dishes containing a solution of $1.25 \mathrm{U} / \mathrm{ml}$ dispase (Boehringer Mannheim, Germany), $0.05 \%$ collagenase (Worthington, USA), and $\mathrm{D}-10$, and were kept under overnight incubation in 5\% CO2 at $37^{\circ} \mathrm{C}$. Following, explants were washed in $\mathrm{D}-10$ and dissociated. The resulting cells were treated with a Thy1.2 antibody (BD Bioscience, USA) and a rabbit serum complement (Calbiochem, USA) for $30 \mathrm{~min}$ at room temperature for fibroblast elimination. The protocol for cell enrichment was described elsewhere (Brockes et al., 1979; White et al., 1983; Dong et al., 1999) and was modified according to our experience. The obtained Schwann cells were then seeded onto laminin (Sigma, USA) coated $100 \mathrm{~mm}$ dishes for expansion. Twenty-four hours later, the culture medium was replaced by a D-10 medium supplemented with $2 \mathrm{mM}$ forskolin (Sigma, USA) and $20 \mathrm{mg} / \mathrm{ml}$ pituitary extract (Gibco, USA). Cells were allowed to expand in that medium until confluence has reached. The medium was changed every other day in the expansion period. The cells of the third passage were used for experiments. Samples of the primary Schwann cell cultures were fixed and immunostained with $S 100 \beta$ antibody and nuclei were stained with diamidino-2-phenylindole (DAPI) for cell type verification, as showed in Figure 3.

Schwann cell total RNA was extracted using Trizol (Life Technologies) according to the manufacturer's protocol. The quantity (NanoDrop 1000 Spectrophotometer) and quality (Agilent 2100 bioanalyser, RNA 6000 Pico LabChip) of RNA were analyzed as described above. Cultured Schwann cell RNA samples were submitted to PCRs in order to access fibroblast contamination; the protocol and results are shown in the supplementary material (Figure S3).

\section{QUANTITATIVE PCR}

Microarray analyses identified the differentially expressed Kif $1 b$ in the spinal cord ( 40 days old mice) and sciatic nerve (60 days old mice) and it was the only gene that its product has been described in the context of ALS (Conforti et al., 2003; Pantelidou et al., 2007). The gene was then selected for verification by $\mathrm{qPCR}$ in the whole spinal cord (40 days old mice) and sciatic nerve (60 days) as well as in the enriched motor neurons and Schwann cells. The qPCR verification was performed on independent samples.

Spinal cord cDNA was synthesized from DNAse-treated $1 \mu \mathrm{g}$ total RNA by employing a TaqMan reverse transcription kit (Applied Biosystems, USA). Sciatic nerve cDNA was synthesized from 100 ng of total RNA by using a Maxima First Strand cDNA Synthesis Kit (Thermo Scientific, USA) according to manufacturers.

qPCR reactions were carried out in duplicate by means of the PikoReal-Time PCR System (Thermo Scientific, USA) employing $40 \mathrm{ng}$ cDNA for spinal cord and $15 \mathrm{ng}$ cDNA for sciatic nerve, the DyNAmo ColorFlash SYBR Green qPCR kit (Thermo Scientific, USA) and finally $400 \mathrm{nM}$ of each primer (Kiflb - Forward 5' $\mathbf{3}^{\prime}$ : 


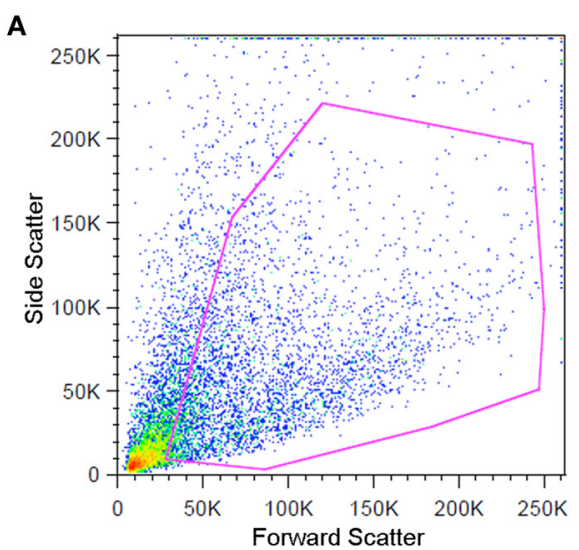

C

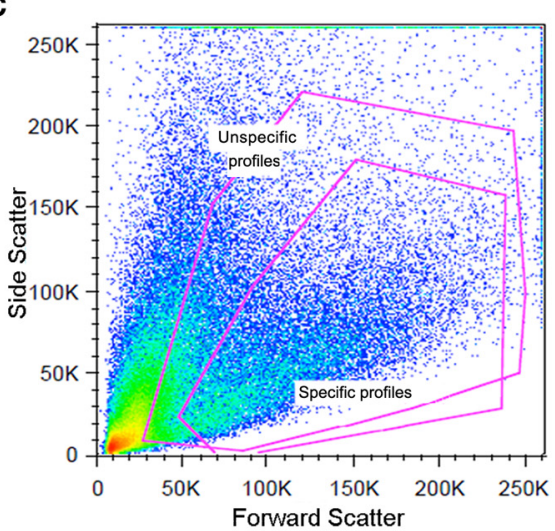

FIGURE 2 | Flow cytometry analysis of Schwann cells from a mouse sciatic nerve employed in the experiments. Dot plots indicate the total number of events in the sciatic nerve cell suspension and the dots inside the red box represent the excluded doublet and dead profiles, which have been eliminated by morphological criteria according to previous descriptions (Shapiro, 2005; Herzenberg et al., 2006) (A). Dot plots of unspecific

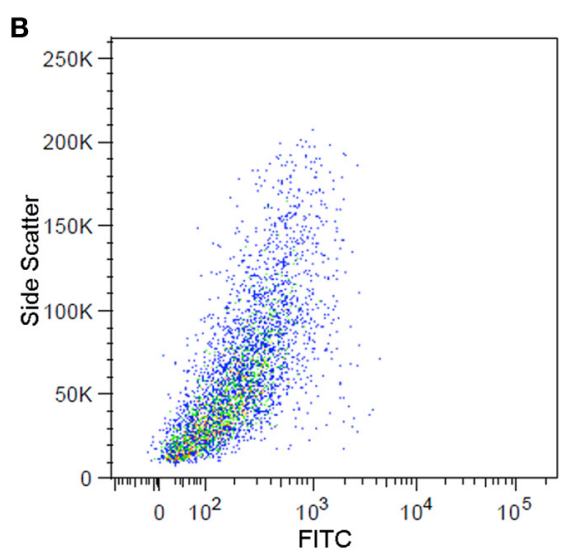

D

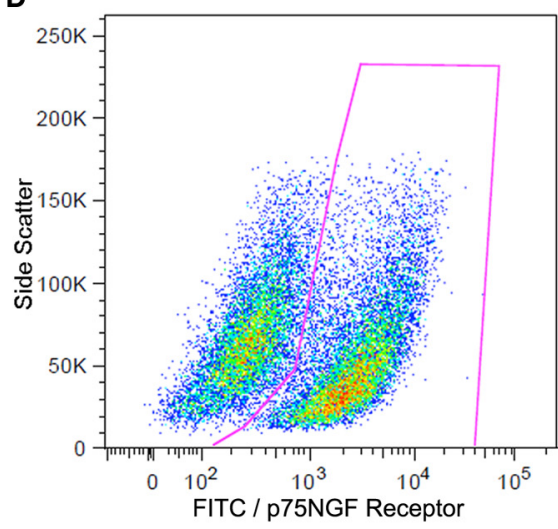

fluorescence are shown in (B). FITIC-conjugated p75NGF receptor antibody was employed in the immunolabeling of Schwann cells (C,D) After morphological criteria, dot plots of labeling profiles (B) were identified as unspecific and specific profiles (red boxes) (C). Specific profiles-based on morphological criteria were further analyzed in relation to fluoresce criteria (B) and the specific p75NGF receptor positive Schwann cells profiles were identified [red box in (D)]
CTGCTAGCCCTTTAAGACTCG; Reverse 5'-3': AAACTCCTAG ACAAACGCTCC; Gapdh-Forward 5'-3': GAGTAAGAAACC CTGGACCAC; Reverse 5'-3': TCTGGGATGGAAATTGTGAGG) in a $20 \mu$ l final volume reaction.

The Kiflb expression was also evaluated in the enriched microdissected Schwann cells and motor neurons as well as in the Schwann cells enriched by means of cell sorting and primary culture procedures. cDNA samples of microdissected cells and of cultured Schwann cells were synthesized from $1 \mu \mathrm{g}$ of amplified RNA as described previously (De Oliveira et al., 2013). The cDNA of flow cytometry sorting Schwann cells was synthesized from 100 ng of total RNA.

The cycling for SYBR reactions was composed by an initial denaturation at $95^{\circ} \mathrm{C}$ for $10 \mathrm{~min}$. Templates were amplified by 40 cycles of $95^{\circ} \mathrm{C}$ for $15 \mathrm{~s}$ and of $60^{\circ} \mathrm{C}$ for $30 \mathrm{~s}$. A dissociation curve was then generated to ensure amplification of a single product and absence of primer dimers. A standard curve was generated for each primer pair in order to determine the efficiency of the PCR reaction over a range of template concentrations from 0.032 to $20 \mathrm{ng} / \mu \mathrm{l}$, using cDNA synthesized from reference mouse
RNA. The efficiency for each set of primers was $100 \pm 5 \%$. Gene expressions, which were normalized by Gapdh, could be determined using the $\Delta \Delta \mathrm{Ct}$ mathematical model (ABI PRISM 7700 Sequence Detection System protocol; Applied Biosystems). Gapdh was chosen as a housekeeping gene to normalize the $\mathrm{qPCR}$ values because the microarray analysis showed no alteration in the gene expression across samples.

\section{STATISTICAL ANALYSIS}

The statistical method employed in the microarray analysis is described above (Hulsen et al., 2008). Furthermore, one-tailed unpaired t-test was used to determine the statistical significance of differences in gene expression [Graphpad Prism 5 (San Diego, $\mathrm{CA})]$ in the qPCR analyses.

\section{RESULTS MICROARRAY ANALYSIS}

The DAVID analysis of differentially expressed genes of 40 days old SOD1 ${ }^{\mathrm{G} 93 \mathrm{~A}}$ mice pointed 34 enriched GO terms under high stringency conditions. The CCO indicated only one GO term 

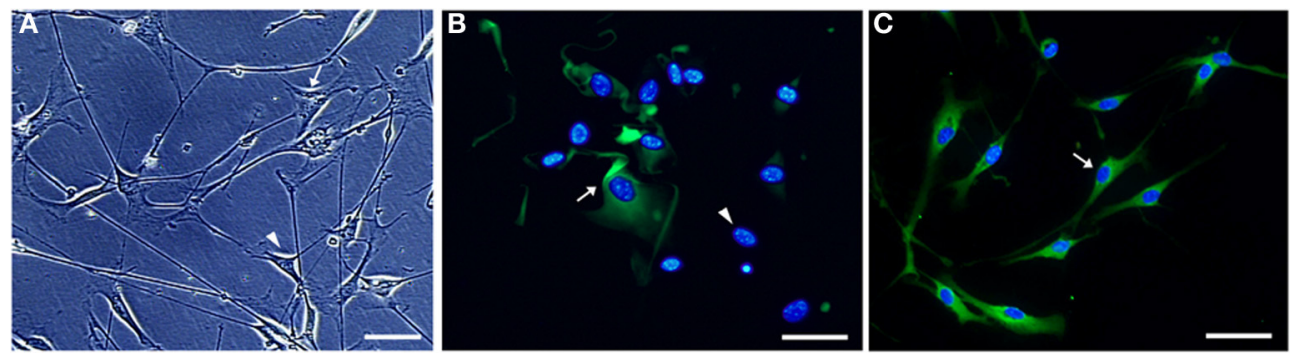

FIGURE 3 | Microphotographs of Schwann cell cultures obtained from sciatic nerve of a 60 days old SOD1 ${ }^{\text {G93A }}$ mouse. Non-purified (A,B) and Thy1.2 antibody/rabbit serum complement-eliminated fibroblast [purified, (C)] Schwann cell cultures are shown under phase-contrast (A) and immunofluorescence (B,C) microscopy. Cultured Schwann cells were evidenced by means of $\mathrm{S} 100$ immunofluorescence (greenish color), and the cell nuclei (bluish color) were stained by DAPI $(\mathbf{B}, \mathbf{C})$. The different morphology of Schwann cells (arrowhead) and fibroblasts (arrow) is observed (A). S100 positive immature Schwann cells (arrow) and DAPI positive nuclei of cells lacking cytoplasmic S100 labeling (arrowhead) are seen in a $24 \mathrm{~h}$ plating non-purified culture (B). Vast majority of S100 immunolabeled Schwann cells possess a homogeneous morphology in a 7-days purified culture after fibroblast elimination [arrow, (C)]. Scale bars: $50 \mu \mathrm{m}$. related to cytoskeleton, the actin cytoskeleton, with 14 genes (six down and eight upregulated), which are shown in Table 1. DAVID also pointed 63 enriched terms from the differentially expressed genes of spinal cord of 80 days old SOD ${ }^{\mathrm{G} 93 \mathrm{~A}}$ mice (Table 2). The CCO indicated five GO terms related to cytoskeleton (Table 2) in the spinal cord of 80 days old SOD1 ${ }^{\mathrm{G} 93 \mathrm{~A}}$ mice, specifically the microtubule cytoskeleton (35 genes), cytoskeleton part (53 genes), actin cytoskeleton (16 genes), neurofilament cytoskeleton (three genes), and cytoskeleton (76 genes). Those genes are overlapped with the 76 deregulated genes of cytoskeleton category ( 25 down and 51 upregulated).

The DAVID analysis also pointed 55 enriched terms from the deregulated genes of sciatic nerve of 60 days old SOD $1^{\mathrm{G} 93 \mathrm{~A}}$ mice. Furthermore, the CCO indicated four GO terms related with cytoskeleton, specifically the actin cytoskeleton (43 genes), cytoskeleton part (101 genes), microtubule cytoskeleton (64 genes), and cytoskeleton (146 genes). The 146 genes of the cytoskeleton GO term (74 down and 72 upregulated) are overlapped with all other GO terms (Table 3).

From the above lists of differentially expressed genes related to cytoskeleton pointed by CCO, nine genes (Dync1li2, Kif1b, Kif1c, Lcp1, Lima1, Myh11, Myo1c, Srcin, Twf1) were deregulated in both spinal cord and sciatic nerve of SOD1 ${ }^{\mathrm{G} 93 \mathrm{~A}}$ mice at the presymptomatic ages 40 and 60 days, respectively, and 10 genes (Abl1, Calm3, Clic5, Dynll2, Krt7, Myl4, Myo1d, Ncs1, Pdlim2, Strbp) were deregulated in the above regions of 80 and 60 days mice, respectively, as shown by the Venn diagram (Figure 4). Furthermore, only the Maea was seen differentially expressed in the spinal cord of 40 and 80 days old presymptomatic SOD 1 G93A mice and no gene appeared to repeat in the three lists of the studied regions of the presymptomatic mice (Figure 4). It should be pointed out that only the Kif $1 b$ from the above described differentially expressed genes related to cytoskeleton has been already mentioned in the context of ALS and has been detailed in the present cellular and molecular analyses.

\section{MOTOR NEURON AND SCHWANN CELL ENRICHMENT}

In order to analyze the modulation of gene expression in specific cell populations possibly involved in the pathogenic mechanisms in ALS, spinal cord motor neurons (lumbar regions) were obtained by means of single cell laser microdissection and the sciatic nerve Schwann cells were achieved by means of laser microdissection, flow cytometry cell sorting and cell culture. The levels of cDNA specific cell type marker that demonstrated the enrichment for each cell type obtained by respective technique are shown in the Supplementary Material (S2, S3).

\section{Kif1 $b$ REGULATION EVIDENCED BY qPCR}

qPCR analyses of Kif1b expression showed an upregulation (1.21 fold) of the gene in spinal cord of presymptomatic 40 days old SOD $1^{\text {G93A }}$ mice (Figure 5A) and a downregulation ( 1.57 fold) in the sciatic nerve of presymptomatic 60 days old transgene mice (Figure 5B). These regulations were coincident and supported the microarray findings. Additionally, qPCR analyses also demonstrated the differentially expression of Kiflb in enriched cell assays using two cycle amplified RNA. Upregulation of Kif1b (24.8 fold) was seen in laser microdissected motor neurons from 40 days old SOD $1^{\mathrm{G} 93 \mathrm{~A}}$ mice (Figure $5 \mathrm{C}$ ); this regulation was in the same direction to that found in the whole spinal cord preparation of 40 days transgene mice by means of microarray and qPCR analyses. Remarkably, Kiflb was downregulated in the enriched sciatic nerve Schwann cells (60 days old SOD1 ${ }^{\mathrm{G} 93 \mathrm{~A}}$ mice) by means of single cell laser microdissection (6.35 fold), cell sorting (3.53 fold), and cell culture (2.70 fold) (Figure 5D), regulations that were in the same direction to that found in the whole sciatic nerve preparation of 60 days transgene mice by means of microarray and $\mathrm{qPCR}$ analyses.

\section{DISCUSSION}

\section{CYTOSKELETON ENRICHMENT ANALYSIS OF GENE PROFILING IN PRESYMPTOMATIC ALS}

Gene regulation of cytoskeleton-related molecules employing microarray technology has been described in the spinal cord and/or microdissected survival neurons from post mortem material of ALS patients (Jiang et al., 2005; Offen et al., 2009; Cox et al., 2010; Tanaka et al., 2012), thus reflecting the cytoskeleton responses to injury instead its role on neurodegenerative triggering. Sporadic and unsystematic results on deregulated 
Table 1 | List of differentially expressed genes in spinal cord of 40 days old SOD1 ${ }^{\mathrm{G} 93 \mathrm{~A}}$ mice related to cytoskeleton.

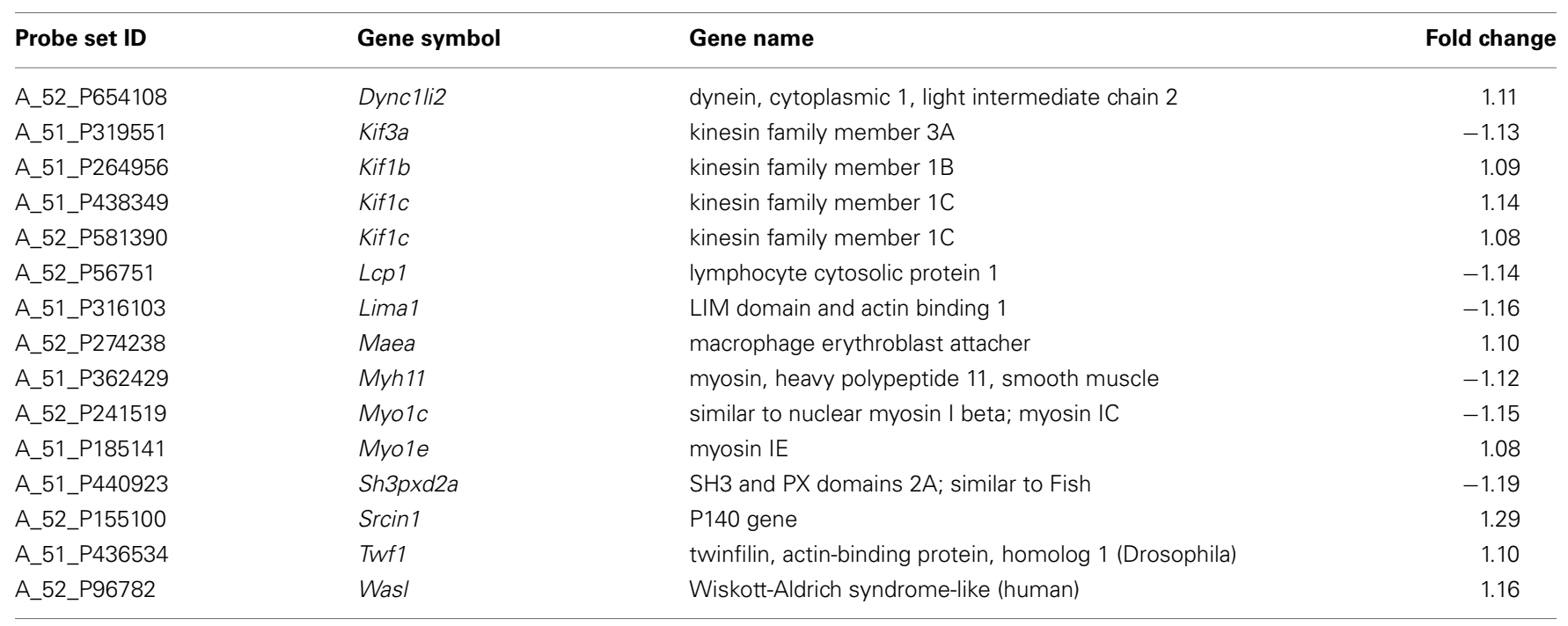

The Kif1c has been demonstrated in the list by two different Probes Set IDs.

genes-related to cytoskeleton in ALS animal models have been demonstrated in several stages of the disease (Perrin et al., 2005; Tanaka et al., 2006; Ferraiuolo et al., 2007; Guipponi et al., 2010; Kudo et al., 2010). The present study extends previous descriptions by detailing gene profiling in expanded categories of cytoskeleton-related genes in the presymptomatic ages of the ALS mouse model. The DAVID analysis was applied by using the full lists of deregulated genes of the spinal cord of 40 and 80 days old presymptomatic ALS mice we have published recently (De Oliveira et al., 2013). Our study has also demonstrated for the first time the gene profiling of cytoskeleton category in the peripheral nerve (sciatic nerve) of the ALS model in a presymptomatic period of the disease.

It should be highlighted the large number of deregulated genes of the cytoskeleton-related category in the spinal cord of presymptomatic ALS mouse of the present study compared to previous descriptions that employed different methodologies (Ferraiuolo et al., 2007; Guipponi et al., 2010; Kudo et al., 2010). In fact, from 13 deregulated genes grouped in categories of cytoskeleton and transport described in the presymptomatic spinal cord of a late onset ALS animal model (Guipponi et al., 2010), the down regulation of kinesin light chain 2 (Klc2) gene was in agreement to our analysis. Also, from 11 deregulated genes of the cytoskeleton and motor activity categories described in microdissected toluidine blue-labeled neurons from the spinal cord of asymptomatic SOD1 ${ }^{\text {G93A }}$ mice (Ferraiuolo et al., 2007), the upregulated Kif $1 b$ and Gsn were found, respectively, in spinal cord of 40 and 80 days old mice of our analysis. Furthermore, similar study that employed a categorization of enriched pathways in asymptomatic ALS mice has not identified cytoskeleton category but pointed six differentially expressed cytoskeleton genes (Kudo et al., 2010).

It is interesting the robust regulation of gene expression in the spinal cord of the ALS mouse model in the presymptomatic phases of the disease, thus underlining the early events on modulation of cytoskeleton elements before the death of spinal cord motor neurons. The genes of cellular components related to cytoskeleton pointed by DAVID enriched analysis showed 14 and 76 deregulated genes in the spinal cord of 40 and 80 days old presymptomatic animals respectively, and 146 deregulated genes in the sciatic nerve of 60 days presymptomatic ALS mice.

In fact, early events regarding impairment of axonal transport, cytoplasm aggregation and neurite/axonal abnormalities have been described before the onset of ALS symptoms (Warita et al., 1999; Williamson and Cleveland, 1999; Magrane and Manfredi, 2009; Rothstein, 2009) and might contribute to the triggering of motor neuron death. Additional novelty of the present analysis was the demonstration of deregulated transcripts-related to cytoskeleton by DAVID categorization in the sciatic nerve of the presymptomatic ALS mice. Gene profiling in the sciatic nerve accounts for axonal (minority) and Schwann cell (majority) transcripts (Baraban et al., 2013; Malmqvist et al., 2014), thus adding an important contribution to molecular analysis on dying back hypothesis of ALS pathology (Dadon-Nachum et al., 2011; De Oliveira et al., 2014).

Despite the evidence of protein synthesis in growing or regenerating axons in vitro and of mRNA axonal transport and local translation in developing zebrafish (Baraban et al., 2013), it is still not clear whether axons of adult motor neurons contain ribosomes and other elements that are necessary for protein translation (Jablonka et al., 2004). Altogether, this manuscript highlights the importance to evaluate the cytoskeleton changes in the Schwann cells in the still poorly described peripheral pathology in ALS (Xiao et al., 2006) and their contribution to impair paracrine trophic actions to motor neurons (unpublished results from our laboratory, presented as an abstract form in the 2013 Society for Neuroscience Meting, San Diego, USA). In order to address this issue, we have developed and presented here different methods to enrich specific cell types for molecular analysis. 
Table 2 | List of differentially expressed genes in spinal cord of 80 days old SOD1 ${ }^{\text {G93A }}$ mice related to cytoskeleton.

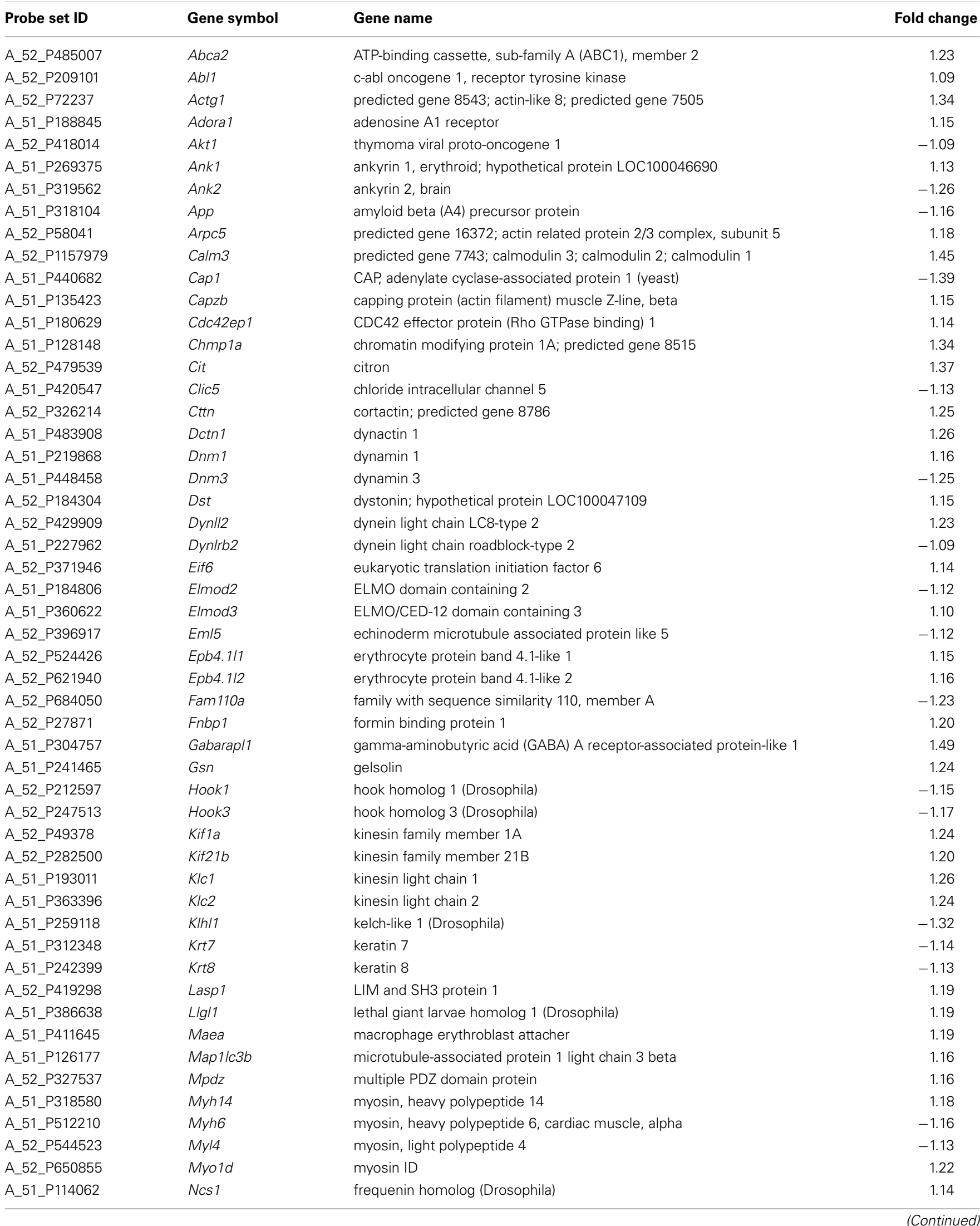


Table 2 | Continued

\begin{tabular}{|c|c|c|c|}
\hline Probe set ID & Gene symbol & Gene name & Fold change \\
\hline A_51_P238933 & Nudc & nuclear distribution gene $\mathrm{C}$ homolog (Aspergillus) & -1.13 \\
\hline A_51_P472726 & Pdlim2 & PDZ and LIM domain 2 & 1.31 \\
\hline A_51_P270478 & Pin4 & $\begin{array}{l}\text { protein (peptidyl-prolyl cis/trans isomerase) NIMA-interacting, } 4 \\
\text { (parvulin) }\end{array}$ & -1.16 \\
\hline A_51_P275679 & Rassf5 & Ras association (RalGDS/AF-6) domain family member 5 & 1.14 \\
\hline A_52_P24320 & Rpgrip1l & Rpgrip1-like & -1.13 \\
\hline A_52_P656024 & Sirt2 & sirtuin 2 (silent mating type information regulation 2, homolog) & 1.19 \\
\hline A_51_P371311 & Slc1a4 & $\begin{array}{l}\text { solute carrier family } 1 \text { (glutamate/neutral amino acid transporter), } \\
\text { member } 4\end{array}$ & 1.13 \\
\hline A_51_P224843 & Tmsb4x & thymosin, beta $4, X$ chromosome; similar to thymosin beta- 4 & -1.21 \\
\hline A_51_P507899 & Ttc8 & tetratricopeptide repeat domain 8 & -1.10 \\
\hline A_51_P169745 & Tuba1a & predicted gene 7172 ; similar to tubulin, alpha 1 ; tubulin, alpha $1 \mathrm{~A}$ & 1.25 \\
\hline A_52_P490023 & Tubb2a & tubulin, beta $2 \mathrm{~A}$ & 1.19 \\
\hline A_52_P621603 & Tubb2a & tubulin, beta $2 \mathrm{~A}$ & 1.26 \\
\hline A_52_P97417 & Tubgcp5 & tubulin, gamma complex associated protein 5 & -1.10 \\
\hline A_52_P266540 & Ubr4 & ubiquitin protein ligase E3 component n-recognin 4 & 1.17 \\
\hline A_52_P569218 & Utrn & utrophin & -1.10 \\
\hline A_51_P361788 & Vapa & vesicle-associated membrane protein, associated protein $A$ & -1.10 \\
\hline A_52_P219314 & Vasp & vasodilator-stimulated phosphoprotein & 1.08 \\
\hline A_51_P473252 & $Z y x$ & zyxin & 1.15 \\
\hline
\end{tabular}

The Tubb2a has been demonstrated in the list by two different Probes Set IDs.

\section{DEREGULATED GENES OF CYTOSKELETON MOLECULES ALREADY POINTED IN ALS}

The description of 14 differentially expressed genes (six down and eight upregulated) in the spinal cord of 40 days old presymptomatic ALS mice already indicates a very early presymptomatic event related to cytoskeleton with a possible implication to physiopathological mechanisms of the disease onset. From those genes, only Kif3a and Kif1b or related molecules have been studied in the context of kinesin dysfunction or impaired anterograde transport of cargos, like neurofilament, in ALS (Dupuis et al., 2000; Conforti et al., 2003; Pantelidou et al., 2007). The Kif3a (downregulation) and Kif1b (upregulation) deregulated genes seen in the spinal cord of 40 days old SOD $1^{\mathrm{G} 93 \mathrm{~A}}$ mice were in line with descriptions of reduction KIF3A $\beta$ in motor cortices of ALS human and animal model (Pantelidou et al., 2007) and of KIF3-associated proteins in ALS rodents (Dupuis et al., 2000), thus underlining the presence of an early and complex mechanism involved in the impairment of the fast anterograde axonal transport machinery in ALS prior motor neuron degeneration.

From the 76 deregulated genes ( 25 down and 51 upregulated) in the spinal cord of 80 days old presymptomatic ALS mice, only eight genes (Actg1, Adora, Akt1, App, Dctn1, Kif1a, Sirt2, and Stmn1) or related molecules have been studied in the context of ALS.
The upregulation of Kifla is in accordance to previous description (Dupuis et al., 2000) and might represent a regulatory mechanism in order to compensate the impaired anterograde transport in neurons. KIF1 is divided into KIF1A, responsible for transport of synaptic vesicle precursors (Okada et al., 1995), and KIF1B, described above, a monomeric motor responsible for the anterograde transport of mitochondria (Nangaku et al., 1994).

Actg1 deregulation described in the spinal cord of 80 days old ALS mice was already mentioned in a previous ALS publication (Baciu et al., 2012) and the related actin product of the gene might impair dendritic spine plasticity with potential implication to motor neuron toxicity in ALS (Sunico et al., 2011). Such a mechanism may also involve an impairment of purinergic receptor-mediated actin cytoskeleton remodeling (Goldman et al., 2013), which is in line with the upregulation of Adoral transcription codifying adenosine A1 receptor, described in this and previous studies (Gundlach et al., 1990).

Dctn1 expression was upregulated in presymptomatic spinal cord (80 days old) of ALS mouse model, thus denoting dynactin impairment as a mechanism in the presymptomatic phase of the disease. Mutation in Dctn1 gene has been associated to motor neuron degeneration in ALS (Hafezparast et al., 2003) and downregulation of the gene was described in residual motor neurons of postmortem material of ALS patients (Jiang et al., 2007). 
Table 3 | List of differentially expressed genes in sciatic nerve of 60 days old SOD1 ${ }^{\text {G93A }}$ mice related to cytoskeleton.

\begin{tabular}{|c|c|c|c|}
\hline Probe set ID & Gene symbol & Gene name & Fold change \\
\hline A_52_P489778 & Ablim1 & actin-binding LIM protein 1 & 1.30 \\
\hline A_52_P420504 & Acta2 & actin, alpha 2, smooth muscle, aorta & 2.08 \\
\hline A_55_P1963807 & $\operatorname{Actg} 2$ & actin, gamma 2, smooth muscle, enteric & 2.45 \\
\hline A_52_P656699 & Actn3 & actinin alpha 3 & 2.81 \\
\hline A_52_P311297 & Als2 & amyotrophic lateral sclerosis 2 (juvenile) homolog (human) & 1.21 \\
\hline A_55_P1979156 & Arap3 & ArfGAP with RhoGAP domain, ankyrin repeat, and $\mathrm{PH}$ domain 3 & 1.21 \\
\hline A_52_P195018 & Arap3 & ArfGAP with RhoGAP domain, ankyrin repeat, and PH domain 3 & 1.32 \\
\hline A_55_P2047986 & Ankrd23 & ankyrin repeat domain 23 & 1.42 \\
\hline A_55_P2021810 & Arc & activity regulated cytoskeletal-associated protein & -1.44 \\
\hline A_52_P153189 & $\operatorname{Ar} / 2 b p$ & ADP-ribosylation factor-like 2 binding protein & -1.16 \\
\hline A_55_P1980636 & Aurka & aurora kinase A; Aurka & -1.27 \\
\hline A_55_P1983768 & Birc5 & baculoviral IAP repeat-containing 5 & -1.23 \\
\hline A_55_P2029106 & $B m f$ & BCL2 modifying factor & 1.28 \\
\hline A_51_P357573 & Cald1 & caldesmon 1 & 1.18 \\
\hline A_52_P140356 & Calm3 & calmodulin 3 & -1.29 \\
\hline A_66_P106654 & Camsap1 & calmodulin regulated spectrin-associated protein 1 & -1.26 \\
\hline A_55_P2065671 & Conb1 & cyclin B1 & -1.60 \\
\hline A_52_P155554 & Cdc42ep2 & CDC42 effector protein (Rho GTPase binding) 2 & -1.24 \\
\hline A_51_P267494 & Cdc42ep3 & CDC42 effector protein (Rho GTPase binding) 3 & 1.54 \\
\hline A_55_P2043269 & Cdc42se1 & CDC42 small effector 1 & -1.20 \\
\hline A_51_P155142 & Cdca8 & cell division cycle associated 8 & -1.17 \\
\hline A_55_P2119907 & Dnahc11 & dynein, axonemal, heavy chain 11 & -1.23 \\
\hline A_52_P485891 & Dnahc5 & dynein, axonemal, heavy chain 5 & -1.20 \\
\hline A_51_P459350 & Dstn & destrin & 1.32 \\
\hline A_55_P2090429 & Dync1i1 & dynein cytoplasmic 1 intermediate chain 1 & -1.43 \\
\hline A_52_P654108 & Dync1li2 & dynein, cytoplasmic 1 light intermediate chain 2 & -1.20 \\
\hline A_51_P203878 & Dynl/2 & dynein light chain LC8-type 2 & -1.17 \\
\hline A_51_P203878 & Dynl/2 & dynein light chain LC8-type 2 & -1.23 \\
\hline A_55_P2069949 & Dynlrb1 & dynein light chain roadblock-type 1 & -1.22 \\
\hline A_55_P2113673 & $E m / 1$ & echinoderm microtubule associated protein like 1 & -1.23 \\
\hline A_55_P1960097 & Epb4.1/3 & erythrocyte protein band 4.1-like 3 & -1.15 \\
\hline A_55_P1956488 & Epb4.9 & erythrocyte protein band 4.9 & 1.26 \\
\hline A_66_P110161 & Eppk1 & epiplakin 1 & 1.34 \\
\hline A_51_P440865 & Fam110b & family with sequence similarity 110 , member $B$ & 1.19 \\
\hline A_51_P512783 & Fam82b & family with sequence similarity 82 , member $B$ & 1.30 \\
\hline A_52_P330395 & Farp1 & FERM, RhoGEF (Arhgef), and pleckstrin domain protein 1 & 1.19 \\
\hline A_55_P2029051 & Fgd3 & FYVE, RhoGEF, and PH domain containing 3 & -1.48 \\
\hline A_52_P493620 & Fgfr1op & Fgfr1 oncogene partner & -1.30 \\
\hline A_51_P495379 & Fhod1 & formin homology 2 domain containing 3 & 1.31 \\
\hline
\end{tabular}


Table 3 | Continued

\begin{tabular}{|c|c|c|c|}
\hline Probe set ID & Gene symbol & Gene name & Fold change \\
\hline A_51_P495379 & Flna & filamin, alpha & 1.31 \\
\hline A_55_P2057537 & Gas7 & growth arrest specific 7 & -1.17 \\
\hline A_55_P2025403 & Gphn & gephyrin & 1.14 \\
\hline A_51_P506748 & Grlf1 & glucocorticoid receptor DNA binding factor 1 & -1.26 \\
\hline A_51_P440460 & Hip1r & huntingtin interacting protein 1 related & 1.15 \\
\hline A_51_P346445 & Hspb7 & heat shock protein family, member 7 (cardiovascular) & 1.36 \\
\hline A_51_P391445 & Ifngr1 & interferon gamma receptor 1 & 1.14 \\
\hline A_55_P1978201 & Incenp & inner centromere protein & -1.29 \\
\hline A_55_P2178044 & Inpp/1 & inositol polyphosphate phosphatase-like 1 & -1.34 \\
\hline A_51_P218653 & Jph2 & junctophilin 2 & 1.26 \\
\hline A_55_P2184741 & Katnal1 & katanin p60 subunit A-like 1 & -1.29 \\
\hline A_65_P12993 & Kif1b & kinesin family member $1 \mathrm{~B}$ & -1.40 \\
\hline A_52_P581390 & Kif1c & kinesin family member $1 \mathrm{C}$ & 1.35 \\
\hline A_51_P133137 & Kif20a & kinesin family member $20 \mathrm{~A}$ & -1.27 \\
\hline A_51_P324287 & Kif23 & kinesin family member 23 & -1.23 \\
\hline A_51_P254805 & Kif4 & kinesin family member 4 & -1.19 \\
\hline A_51_P107020 & Kif5a & kinesin family member $5 \mathrm{~A}$ & 1.25 \\
\hline A_66_P116311 & Kif5b & kinesin family member 5B & -1.20 \\
\hline A_55_P2048937 & Kif5c & kinesin family member $5 \mathrm{C}$ & 1.42 \\
\hline A_51_P154753 & KIc3 & kinesin light chain 3 & -1.37 \\
\hline A_52_P410685 & Krt7 & keratin 7 & 1.16 \\
\hline A_55_P2142151 & Mapk1ip1 & mitogen-activated protein kinase 1 interacting protein 1 & 1.23 \\
\hline A_55_P1954486 & Mapt & microtubule-associated protein tau & -1.17 \\
\hline A_55_P2004777 & Micall2 & MICAL-like 2 & -1.42 \\
\hline A_51_P124568 & Mpp1 & membrane protein, palmitoylated & 1.54 \\
\hline A_55_P2147280 & Myh1 & myosin, heavy polypeptide 1 , skeletal muscle, adult & 2.80 \\
\hline A_55_P1988531 & Myh11 & myosin, heavy polypeptide 11, smooth muscle & 2.35 \\
\hline A_51_P416858 & Myl1 & myosin, light polypeptide 1 & 5.53 \\
\hline A_66_P107790 & Myl12a & myosin, light chain $12 \mathrm{~A}$ & 1.44 \\
\hline A_55_P2107045 & Myl4 & myosin, light polypeptide 4 & 1.20 \\
\hline A_51_P308298 & Myl9 & myosin, light polypeptide 9, regulatory & 1.33 \\
\hline A_51_P324303 & Mylip & myosin regulatory light chain interacting protein & -1.18 \\
\hline A_55_P2154049 & Myo18a & myosin XVIIIA & -1.18 \\
\hline A_55_P1955034 & Myo1c & similar to nuclear myosin I beta; myosin IC & 1.20 \\
\hline A_52_P650855 & Myo1d & myosin ID & 1.27 \\
\hline A_55_P2006250 & Myo5a & myosin VA & -1.19 \\
\hline A_66_P115949 & Myo9a & myosin Ixa & -1.15 \\
\hline A_51_P114062 & Ncs1 & neuronal calcium sensor 1 & -1.19 \\
\hline A_55_P2116978 & $\mathrm{Neb}$ & nebulin & 1.52 \\
\hline A_52_P367520 & Nexn & nexilin & 1.16 \\
\hline
\end{tabular}


Table 3 | Continued

\begin{tabular}{|c|c|c|c|}
\hline Probe set ID & Gene symbol & Gene name & Fold change \\
\hline A_55_P2423646 & Nf2 & neurofibromatosis 2 & 1.21 \\
\hline A_55_P2155582 & Nin & ninein & -1.24 \\
\hline A_55_P2158741 & Nos2 & nitric oxide synthase 2, inducible & -1.26 \\
\hline A_51_P139651 & Nos3 & nitric oxide synthase 3, endothelial cel & 1.55 \\
\hline A_51_P240453 & Nusap1 & nucleolar and spindle associated protein 1 & -1.23 \\
\hline A_55_P2058137 & Pde4dip & phosphodiesterase 4D interacting protein (myomegalin) & 2.21 \\
\hline A_51_P472726 & Pdlim2 & PDZ and LIM domain 2 & 1.43 \\
\hline A_52_P579531 & Pdlim3 & PDZ and LIM domain 3 & 2.07 \\
\hline A_55_P2004571 & Pitpnm2 & phosphatidylinositol transfer protein, membrane-associated 2 & 1.17 \\
\hline A_52_P234729 & $P k d 2$ & polycystic kidney disease 2 & -1.27 \\
\hline A_52_P668285 & Plk4 & polo-like kinase 4 & -1.19 \\
\hline A_55_P1988083 & $\operatorname{Prc1}$ & protein regulator of cytokinesis 1 & -1.38 \\
\hline A_51_P382152 & Procr & protein C receptor, endothelial & 1.50 \\
\hline A_55_P2429225 & Psrc1 & proline/serine-rich coiled-coil 1 & -1.18 \\
\hline A_51_P455946 & Rac3 & RAS-related C3 botulinum substrate 3 & -1.19 \\
\hline A_55_P2127702 & Racgap 1 & Rac GTPase-activating protein 1 & -1.20 \\
\hline A_51_P221337 & Ranbp10 & RAN binding protein 10 & 1.16 \\
\hline A_52_P76034 & Rcc2 & regulator of chromosome condensation 2 & -1.18 \\
\hline A_51_P227392 & Rhou & ras homolog gene family, member $U$ & -1.32 \\
\hline A_51_P435922 & Rsph9 & radial spoke head 9 homolog (Chlamydomonas) & -1.44 \\
\hline A_55_P2168628 & Sac3d1 & SAC3 domain containing 1 & -1.14 \\
\hline A_51_P389004 & Sgcd & sarcoglycan, delta (dystrophin-associated glycoprotein) & 1.17 \\
\hline A_51_P115626 & Shank3 & SH3/ankyrin domain gene 3 & 1.22 \\
\hline A_52_P78373 & Sorbs3 & sorbin and $\mathrm{SH} 3$ domain containing 3 & 1.31 \\
\hline A_51_P513530 & Spag5 & sperm associated antigen 5 & -1.28 \\
\hline A_51_P348652 & Spast & spastin & -1.34 \\
\hline A_51_P386870 & Sprr2f & small proline-rich protein $2 \mathrm{~F}$ & -1.19 \\
\hline A_55_P2081123 & $\operatorname{Srcin} 1$ & SRC kinase signaling inhibitor 1 & -0.30 \\
\hline A_55_P1988043 & Ssh1 & slingshot homolog 1 (Drosophila) & -1.15 \\
\hline A_55_P1968977 & Stk38I & serine/threonine kinase 38 like & -1.19 \\
\hline A_52_P639064 & Strbp & spermatid perinuclear RNA binding protein & -1.23 \\
\hline A_51_P123676 & Synpo & synaptopodin & 1.19 \\
\hline A_55_P2004801 & Tacc3 & transforming, acidic coiled-coil containing protein 3 & -1.18 \\
\hline A_51_P429276 & Tmod3 & tropomodulin 3 & 1.36 \\
\hline A_55_P2008895 & Tmsb15b1 & thymosin beta $15 b 1$ & 1.41 \\
\hline A_52_P315976 & Tpm2 & tropomyosin 2, beta & 2.00 \\
\hline A_55_P2121408 & Tpm2 & tropomyosin 2, beta & 2.29 \\
\hline A_51_P369200 & $T p \times 2$ & TPX2, microtubule-associated protein homolog (Xenopus laevis) & -1.20 \\
\hline A_51_P208697 & Ttl & tubulin tyrosine ligase & -1.43 \\
\hline A_66_P119518 & Tuba8 & tubulin, alpha 8 & -1.24 \\
\hline A_51_P514256 & $T u b b 2 b$ & tubulin, beta 2B class IIB & -1.34 \\
\hline A_55_P2034864 & $T u b b 2 b$ & tubulin, beta 2B class IIB & -1.32 \\
\hline A_55_P2013645 & Tubg2 & tubulin, gamma 2 & 1.17 \\
\hline A_51_P226932 & Tubgcp2 & tubulin, gamma complex associated protein 2 & 1.18 \\
\hline A_52_P484405 & Twf1 & twinfilin, actin-binding protein, homolog 1 (Drosophila) & -1.15 \\
\hline A_52_P190973 & $\mathrm{Vcl}$ & vinculin & 1.25 \\
\hline A_55_P1963443 & Vps18 & vacuolar protein sorting 18 (yeast) & 1.17 \\
\hline
\end{tabular}

Each Arap3, Atm, Dynll2, Tpm2, and Tubb2b have been demonstrated in the list by two different Probes Set IDs.

There is a lack of information on dynactin regulation before clinical onset of ALS despite the fact that dynein-dynactin complex, the only retrograde transport motor, contributes to formation of SOD1 inclusions in the disease (Strom et al., 2008). Furthermore, deregulation of Schwann cell genes related to neurothropindependent mechanisms in association to an impaired axonal transport may enhance motor neuron vulnerability in ALS (Koh et al., 2005; Niewiadomska et al., 2011). 


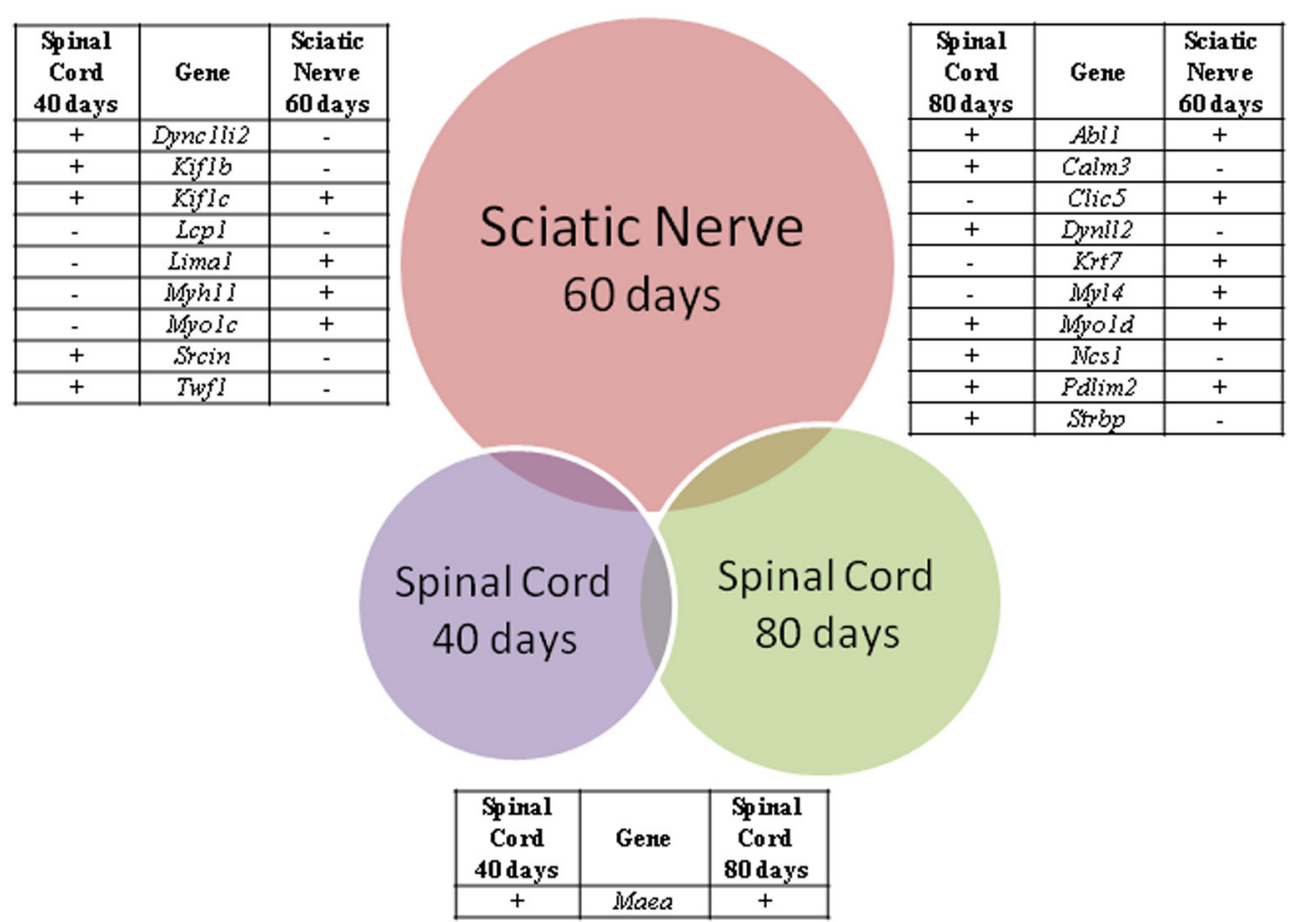

FIGURE 4 | Venn diagram of differentially expressed genes related to cytoskeleton analysis in spinal cords (40 and 80 days) and sciatic nerve (60 days) of SOD1 ${ }^{\text {G93A }}$ animals compared to wild-type controls by means of microarray experiments. The enrichment cytoskeleton lists were obtained by means of DAVID tool based on Cellular Component Ontology, which identified 146 differentially expressed genes in the sciatic nerve from 60 days old mice, 76 genes in spinal cord from 80 days old mice and 14 genes in spinal cord from 40 days old mice. Venn diagram demonstrated nine genes common between sciatic nerve and 40 days old mouse spinal cord, 10 genes common between sciatic nerve and 80 days old mouse spinal cord, and only one gene common between spinal cord groups. Positive $(+)$ and negative $(-)$ signals represent the upregulated and the down regulated genes, respectively.
The upregulation of Sirt2 expression in the spinal cord of 80 days old mice might trigger toxicicity to motor neurons in the late stage of the presymptomatic age by increasing deacetylation of alfa tubulin (Korner et al., 2013; Taes et al., 2013). Moreover, the upregulation of Stmn1 in the ALS spinal cord before neuronal death is in agreement to previous description on stathmin protein accumulation in spinal cord motor neurons leading to Gogi apparatus fragmentation and collapse of microtubule network (Strey et al., 2004). Furthermore, the formation of perikaryal/axonal intermediate filament inclusions, neurofilament abnormalities and genetic defects in microtubule-based transport that may facilitate the elevation of the toxic amyloid beta precursor in ALS (Spadoni et al., 2009; Bryson et al., 2012) might correlate the downregulation of App seen in the spinal cord of 80 days presymptomatic phase to a neuroprotective regulation before the neuronal death onset.

Finally, the downregulation of Vapa in the spinal cord of 80 days old ALS mice is also an original and interesting finding of the present analysis. VAMP/synaptobrevin-associated proteins A and B (VAPA and VAPB) are both enriched on endoplasmic reticulum and Golgi membranes and are capable to interact with cytoskeleton elements in order to maintain the organelle morphology (Nishimura et al., 1999). Despite a lack of information on VAPA function in the central nervous system, VAPB mutation is associated to a familial form of ALS (Nishimura et al., 2004).
It should be pointed out the regulation Maea, the unique gene that was overexpressed in the spinal cord of both 40 and 80 days old ALS mice, indicating its long lasting involvement in the presymptomatic events in the ALS spinal cord. The role of Maea in ALS is unknown but it could participate in the immunomodulatory signaling of non-neuronal cells-induced toxicity in ALS (Levine et al., 1999; McGeer and McGeer, 2002; Pasinelli and Brown, 2006).

From the 146 deregulated genes ( 74 down and 72 upregulated) in the sciatic nerve of 60 days presymptomatic old SOD $1^{\mathrm{G} 93 \mathrm{~A}}$ old mice, only 10 genes or related molecules have been studied in context of ALS.

The downregulation of the Aif1, Ccnb1, and Mapt in the presymptomatic ALS mice is likely to participate in the early events in the ALS peripheral nerve pathology. Aif1 encodes the allograft inflammatory factor-1 (AIF-1) and AIF-1 positive microglia/macrophages are among the earliest cells to respond to nerve injury (Schwab et al., 2001). It is likely that AIF-1 may act as an initiator of the early microglial/macrophage-induced immunomodulation leading a motor axon retraction and neuromuscular junction disruption before neuronal degeneration (Dibaj et al., 2011). Furthermore, Ccnb1 deregulation-induced cytoskeleton disorganization (Husseman et al., 2000) and also altered neuronal cytoskeleton protein Tau encoded by Mapt induced microtubule stabilization and assembly deregulation 


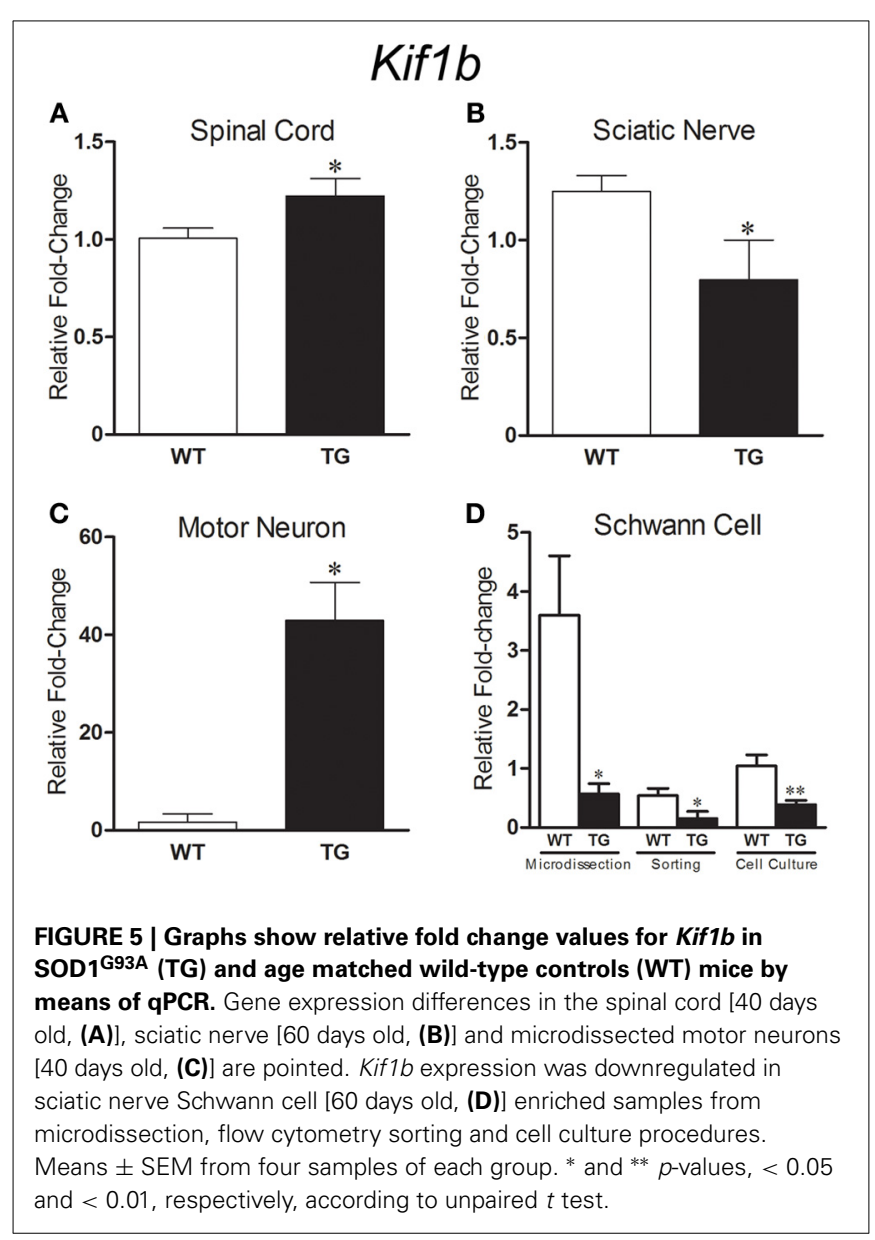

(Aronov et al., 2002) are possible mechanisms related to early axonal retraction taking place in presymptomatic phases of the disease (Aronov et al., 2002).

Actn3, Als2, Kif5a, Kif5c, Nos3, and Tmod3 were found upregulated in the sciatic nerve of 60 days old presymptomatic ALS mice and their related molecules have been mentioned in the context of ALS mechanisms. ACTN3, one of the four human alpha-actinin isoforms, has been associated to ALS progression in human muscle (Pradat et al., 2012; Bernardini et al., 2013). Moreover, the upregulated Tmod3, which codifies the tropomodulin (TMOD), an actin-capping protein for the slow-growing end of filamentous actin (Ito et al., 1995), may represent a need for the dynamic polymerization of actin cytoskeleton, probably in the Schwann cells of ALS nerve. Interestingly, the mutation of ubiquitously expressed TMOD3 protein is responsible for type 5 familial ALS (Cox and Zoghbi, 2000). Furthermore, despite ALS2 deficiency accounts for ALS2 familial form (Hadano et al., 2001; Yang et al., 2001), the upregulation of Als2 seen in the 60 days old presymptomatic ALS sciatic nerve could reflect a transient Schwann cell neuroprotective paracrine response (Hadano et al., 2010). In fact, ALS2/alsin, a guanine nucleotide exchange factor for GTPase Rab5, is involved in endosome fusion/trafficking, neurite outgrowth and corticospinal axon integrity (Deng et al., 2007; Lai et al., 2009), probably by interfering with the accumulation of immature vesicles and misfolded proteins (Lai et al., 2009).
We have also found a deregulation of the Nos 2 and Nos3 expression in sciatic nerve of 60 days old ALS mice, without changes in presymptomatic spinal cord. The synthesis of inducible NOS in the spinal cord and peripheral nerve of ALS model in the presymptomatic phase of the disease has been mentioned (Almer et al., 1999; Chen et al., 2010).

Important finding of the present study was also the regulation of several genes of kinesin molecules in the sciatic nerve of 60 days old presymptomatic ALS mice. The differential Kif5 regulation in the sciatic nerve observed in our microarray analysis may in fact represent the gene regulation in the Schwann cells where the KIF5 participate in the myelin integrity (Bolis et al., 2009). In this context, KIF5B might be of substantial interest because it also expresses in non-neuronal cells and its regulation/activity has not been explored in ALS mechanisms. Further evidence for KIF5 mechanisms in non-neuronal cells were obtained from the absence of Kif5 expression in the spinal cord of presymptomatic SOD ${ }^{\mathrm{G} 93 \mathrm{~A}}$ mice by gene profiling study (this work) and qPCR analysis (Kuzma-Kozakiewicz et al., 2013).

\section{TOPOGRAPHIC AND CELLULAR MODULATION OF Kif1b OF KINESIN FAMILY}

The downregulation of Kif1b in the sciatic nerve showed by microarray and qPCR was in the opposite direction to the upregulation of the gene seen in the spinal cord of presymptomatic ALS mice. Importantly, only the Kif $1 b$ was deregulated in the two evaluated regions and also was reported previously in the context of ALS (Ferraiuolo et al., 2007; Kuzma-Kozakiewicz et al., 2013). Furthermore, it is the first time Kif1b expression or its protein has been described in Schwann cells. The development of technology to enrich Schwann cells allowed the present analysis.

Kiflb deregulation in presymptomatic ALS seems to be an important event, specially in the Schwann cells because KIF1B is required for adequate myelination process by oligodendrocytes (Lyons et al., 2009). Presently, myelin pathology is not clear in ALS peripheral nerves (Heads et al., 1991). Nonetheless, it is still undefined whether peripheral myelin morphological alteration in ALS is a consequence of axonal degeneration (Perrie et al., 1993).

There is a lack of information on myelin alterations in peripheral nerves of presymptomatic ALS mice and it is uncertain whether impairments in the Schwann cell function could contribute to ALS axonal pathology and dying back events. That is actually an important issue in the pathogenic mechanism of the disease because myelin cell function overtakes action potential conduction along peripheral axons (Monk and Talbot, 2009). In fact, the control of axoplasmic $\mathrm{Ca}^{2+}$ and posttranslational modifications of local trafficking proteins are part of trophic support signaling provided by myelinating cells. We might speculate that an impaired crosstalk between Schwann cell and motor axon in presymptomatic stages of the disease could trigger axonal retraction and Wallerian degeneration (Lyons et al., 2009; Kiryu-Seo and Kiyama, 2011; Gentil and Cooper, 2012).

The above discussion indicates the importance to evaluate the events in specific cell types notably in the context of peripheral nerve-induced neuropathology in ALS, because a differential regulation can occur specifically in Schwann cells and also altered 
axonal transport might modify the local traffic of RNAs (Ticozzi et al., 2010).

Single cell laser microdissection has been employed by our group and other researchers to evaluate gene expression on enriched cell types (Ferraiuolo et al., 2007; De Oliveira et al., 2009; Guipponi et al., 2010; Kudo et al., 2010; Tanaka et al., 2012). We have developed and showed here for the first time the method to immunolabel mouse Schwann cells and motor neurons and also the procedures to enrich cell samples for molecular analyses by means of single cell laser microdissection. We have also developed and demonstrated in this work the methodology to enrich mouse Schwann cells by means of primary cell culture and cell sorting. We still do not know precisely the limitations of the enrichment techniques employed here. Nevertheless, it should be emphasized the agreement of the results obtained by the different methods.

It is of substantial importance that the methodology allowed the observation of a differential regulation of Kif $1 B$ in the enriched ChAT immunolabeled motor neurons (upregulation) and Schwann cells (downregulation). The results were coincident to those obtained in qPCR and microarray analyses of whole spinal cord and sciatic nerve of presymptomatic ALS mice.

A differential gene regulation in specific cell types in a neuroglial unit, the motor neuron-Schwann cell unit in this case, highlights the complexity of cellular and molecular mechanisms of ALS, remarkably before clinical onset. Kif1b upregulation in immunolabeled motor neurons was in line to a previous work that employed toluidine blue-enriched putative motor neurons of presymptomatic ALS mice (Ferraiuolo et al., 2007). This finding indicates an involvement of a motor protein of kinesin family in the axonal trafficking before the death of motor neurons and the appearance of neurological symptoms. The elevation of the protein in ALS neurons might be a substrate for an increased kinesin-1 phosphorylation and a diminution of kinesin-1 function with a subsequent defect of fast axonal transport (Morfini et al., 2013).

The Kif1b downregulation in the sciatic nerve and also in the enriched Schwann cells of presymptomatic ALS mice is a major original contribution of the present work. The recent description on the role of KIF1B for the adequate function of central myelinating cells (Lyons et al., 2009; Gentil and Cooper, 2012) opens up the possibly for the existence of KIF1B mechanisms in the paracrine trophic actions of Schwann cells to peripheral motor neurons. Deregulated KIF1B in Schwann cells highlights the possibility of no autonomous cell toxicity of Schwann cells to motor neurons in ALS, mechanisms that should be investigated in details in future works. In fact, the non-autonomous cell toxicity of central glia to motor neurons has been described (Boillee et al., 2006a) and the related molecular pathways are under investigation.

In conclusion, the present work demonstrated cytoskeleton gene regulation as an important occurrence in motor neurons and Schwann cells in the presymptomatic stages of ALS and may be of importance in the dying back mechanisms of neuronal death in the neurodegenerative disease. The differential regulation of $K$ if $1 b$ in the spinal cord (upregulation) and sciatic nerve (downregulation) was coincident to that found in the enriched motor neurons and Schwann cells and emerged as an important event in the pathogenic mechanism of ALS.

\section{AUTHOR CONTRIBUTIONS}

Jessica R. Maximino, Gabriela P. de Oliveira, and Chrystian J. Alves performed the experiments. Jessica R. Maximino and Gerson Chadi designed the study and analyzed the results. Gerson Chadi wrote the manuscript. All authors read and approved the final manuscript.

\section{ACKNOWLEDGMENTS}

Grant \#2010/20457-7, São Paulo Research Foundation (FAPESP) and $\mathrm{CNPq}$.

\section{SUPPLEMENTARY MATERIAL}

The Supplementary Material for this article can be found online at: http://www.frontiersin.org/journal/10.3389/fncel.2014. 00148/abstract

\section{REFERENCES}

Almer, G., Vukosavic, S., Romero, N., and Przedborski, S. (1999). Inducible nitric oxide synthase up-regulation in a transgenic mouse model of familial amyotrophic lateral sclerosis. J. Neurochem. 72, 2415-2425. doi: 10.1046/j.14714159.1999.0722415.x

Alves, C. J., De Santana, L. P., Dos Santos, A. J., De Oliveira, G. P., Duobles, T., Scorisa, J. M., et al. (2011). Early motor and electrophysiological changes in transgenic mouse model of amyotrophic lateral sclerosis and gender differences on clinical outcome. Brain Res. 1394, 90-104. doi: 10.1016/j.brainres.2011.02.060

Aronov, S., Aranda, G., Behar, L., and Ginzburg, I. (2002). Visualization of translated tau protein in the axons of neuronal P19 cells and characterization of tau RNP granules. J. Cell Sci. 115, 3817-3827. doi: 10.1242/jcs.00058

Baciu, C., Thompson, K. J., Mougeot, J. L., Brooks, B. R., and Weller, J. W. (2012). The LO-BaFL method and ALS microarray expression analysis. BMC Bioinformatics 13, 244. doi: 10.1186/1471-2105-13-244

Baraban, M., Anselme, I., Schneider-Maunoury, S., and Giudicelli, F. (2013). Zebrafish embryonic neurons transport messenger RNA to axons and growth cones in vivo. J. Neurosci. 33, 15726-15734. doi: 10.1523/JNEUROSCI.151013.2013

Bernardini, C., Censi, F., Lattanzi, W., Barba, M., Calcagnini, G., Giuliani, A., et al. (2013). Mitochondrial network genes in the skeletal muscle of amyotrophic lateral sclerosis patients. PLoS ONE 8:e57739. doi: 10.1371/journal.pone.0057739

Boillee, S., Vande Velde, C., and Cleveland, D. W. (2006a). ALS: a disease of motor neurons and their nonneuronal neighbors. Neuron 52, 39-59. doi: 10.1016/j.neuron.2006.09.018

Boillee, S., Yamanaka, K., Lobsiger, C. S., Copeland, N. G., Jenkins, N. A., Kassiotis, G., et al. (2006b). Onset and progression in inherited ALS determined by motor neurons and microglia. Science 312, 1389-1392. doi: 10.1126/science.1123511

Bolis, A., Coviello, S., Visigalli, I., Taveggia, C., Bachi, A., Chishti, A. H., et al. (2009). Dlg1, Sec8, and Mtmr2 regulate membrane homeostasis in Schwann cell myelination. J. Neurosci. 29, 8858-8870. doi: 10.1523/JNEUROSCI.142309.2009

Boutahar, N., Wierinckx, A., Camdessanche, J. P., Antoine, J. C., Reynaud, E., Lassabliere, F., et al. (2011). Differential effect of oxidative or excitotoxic stress on the transcriptional profile of amyotrophic lateral sclerosis-linked mutant SOD1 cultured neurons. J. Neurosci. Res. 89, 1439-1450. doi: 10.1002/jnr. 22672

Brockes, J. P., Fields, K. L., and Raff, M. C. (1979). Studies on cultured rat Schwann cells. I. Establishment of purified populations from cultures of peripheral nerve. Brain Res. 165, 105-118.

Bryson, J. B., Hobbs, C., Parsons, M. J., Bosch, K. D., Pandraud, A., Walsh, F. S. et al. (2012). Amyloid precursor protein (APP) contributes to pathology in the SOD1(G93A) mouse model of amyotrophic lateral sclerosis. Hum. Mol. Genet. 21, 3871-3882. doi: $10.1093 / \mathrm{hmg} / \mathrm{dds} 215$ 
Chen, K., Northington, F. J., and Martin, L. J. (2010). Inducible nitric oxide synthase is present in motor neuron mitochondria and Schwann cells and contributes to disease mechanisms in ALS mice. Brain Struct. Funct. 214, 219-234. doi: 10.1007/s00429-009-0226-4

Conforti, L., Dell'agnello, C., Calvaresi, N., Tortarolo, M., Giorgini, A., Coleman, M. P., et al. (2003). Kif1Bbeta isoform is enriched in motor neurons but does not change in a mouse model of amyotrophic lateral sclerosis. J. Neurosci. Res. 71, 732-739. doi: 10.1002/jnr.10517

Cooper-Knock, J., Kirby, J., Ferraiuolo, L., Heath, P. R., Rattray, M., and Shaw, P. J. (2012). Gene expression profiling in human neurodegenerative disease. Nat. Rev. Neurol. 8, 518-530. doi: 10.1038/nrneurol.2012.156

Cox, L. E., Ferraiuolo, L., Goodall, E. F., Heath, P. R., Higginbottom, A., Mortiboys, H., et al. (2010). Mutations in CHMP2B in lower motor neuron predominant amyotrophic lateral sclerosis (ALS). PLoS ONE 5:e9872. doi: 10.1371/journal.pone.0009872

Cox, P. R., and Zoghbi, H. Y. (2000). Sequencing, expression analysis, and mapping of three unique human tropomodulin genes and their mouse orthologs. Genomics 63, 97-107. doi: 10.1006/geno.1999.6061

Dadon-Nachum, M., Melamed, E., and Offen, D. (2011). The "dying-back" phenomenon of motor neurons in ALS. J. Mol. Neurosci. 43, 470-477. doi: 10.1007/s12031-010-9467-1

Dangond, F., Hwang, D., Camelo, S., Pasinelli, P., Frosch, M. P., Stephanopoulos, G., et al. (2004). Molecular signature of late-stage human ALS revealed by expression profiling of postmortem spinal cord gray matter. Physiol. Genomics 16, 229-239. doi: 10.1152/physiolgenomics.00087.2001

Deng, H. X., Zhai, H., Fu, R., Shi, Y., Gorrie, G. H., Yang, Y., et al. (2007). Distal axonopathy in an alsin-deficient mouse model. Hum. Mol. Genet. 16, 2911-2920. doi: 10.1093/hmg/ddm251

De Oliveira, G. P., Alves, C. J., and Chadi, G. (2013). Early gene expression changes in spinal cord from SOD1(G93A) Amyotrophic Lateral Sclerosis animal model. Front. Cell Neurosci. 7:216. doi: 10.3389/fncel.2013.00216

De Oliveira, G. P., Maximino, J. R., Lin, C. J., and Chadi, G. (2009). A method to immunolabel rodent spinal cord neurons and glia for molecular study in specific laser microdissected cells involved in neurodegenerative disorders. J. Mol. Histol. 40, 217-225. doi: 10.1007/s10735-009-9233-2

De Oliveira, G. P., Maximino, J. R., Maschietto, M., Zanoteli, E., Puga, R. D., Lima, L., et al. (2014). Early gene expression changes in skeletal muscle from SOD1(G93A) amyotrophic lateral sclerosis animal model. Cell. Mol. Neurobiol. 34, 451-462. doi: 10.1007/s10571-014-0029-x

De Winter, F., Vo, T., Stam, F. J., Wisman, L. A., Bar, P. R., Niclou, S. P., et al. (2006). The expression of the chemorepellent Semaphorin 3A is selectively induced in terminal Schwann cells of a subset of neuromuscular synapses that display limited anatomical plasticity and enhanced vulnerability in motor neuron disease. Mol. Cell. Neurosci. 32, 102-117. doi: 10.1016/j.mcn.2006.03.002

Dibaj, P., Steffens, H., Zschuntzsch, J., Nadrigny, F., Schomburg, E. D., Kirchhoff, F., et al. (2011). In Vivo imaging reveals distinct inflammatory activity of CNS microglia versus PNS macrophages in a mouse model for ALS. PLoS ONE 6:e17910. doi: 10.1371/journal.pone.0017910

Dong, Z., Sinanan, A., Parkinson, D., Parmantier, E., Mirsky, R., and Jessen, K. R. (1999). Schwann cell development in embryonic mouse nerves. J. Neurosci. Res. 56, 334-348. doi: 10.1002/(SICI) 1097-4547(19990515)56:4<334::AID-JNR2>3. $0 . \mathrm{CO} ; 2-\#$

Dupuis, L., De Tapia, M., Rene, F., Lutz-Bucher, B., Gordon, J. W., Mercken, L., et al. (2000). Differential screening of mutated SOD1 transgenic mice reveals early up-regulation of a fast axonal transport component in spinal cord motor neurons. Neurobiol. Dis. 7, 274-285. doi: 10.1006/nbdi.2000.0292

Ferraiuolo, L., De Bono, J. P., Heath, P. R., Holden, H., Kasher, P., Channon, K. M., et al. (2009). Transcriptional response of the neuromuscular system to exercise training and potential implications for ALS. J. Neurochem. 109, 1714-1724. doi: 10.1111/j.1471-4159.2009.06080.x

Ferraiuolo, L., Heath, P. R., Holden, H., Kasher, P., Kirby, J., and Shaw, P. J. (2007). Microarray analysis of the cellular pathways involved in the adaptation to and progression of motor neuron injury in the SOD1 G93A mouse model of familial ALS. J. Neurosci. 27, 9201-9219. doi: 10.1523/JNEUROSCI.1470-07.2007

Ferraiuolo, L., Kirby, J., Grierson, A. J., Sendtner, M., and Shaw, P. J. (2011). Molecular pathways of motor neuron injury in amyotrophic lateral sclerosis. Nat. Rev. Neurol. 7, 616-630. doi: 10.1038/nrneurol.2011.152

Fischer, L. R., Culver, D. G., Tennant, P., Davis, A. A., Wang, M., CastellanoSanchez, A., et al. (2004). Amyotrophic lateral sclerosis is a distal axonopathy: evidence in mice and man. Exp. Neurol. 185, 232-240. doi: 10.1016/j.expneurol.2003.10.004

Fukada, Y., Yasui, K., Kitayama, M., Doi, K., Nakano, T., Watanabe, Y., et al. (2007). Gene expression analysis of the murine model of amyotrophic lateral sclerosis: studies of the Leu126delTT mutation in SOD1. Brain Res. 1160, 1-10. doi: 10.1016/j.brainres.2007.05.044

Gama Sosa, M. A., De Gasperi, R., and Elder, G. A. (2012). Modeling human neurodegenerative diseases in transgenic systems. Hum. Genet. 131, 535-563. doi: 10.1007/s00439-011-1119-1

Gentil, B. J., and Cooper, L. (2012). Molecular basis of axonal dysfunction and traffic impairments in CMT. Brain Res. Bull. 88, 444-453. doi: 10.1016/j.brainresbull.2012.05.003

Gentleman, R. C., Carey, V. J., Bates, D. M., Bolstad, B., Dettling, M., Dudoit, S., et al. (2004). Bioconductor: open software development for computational biology and bioinformatics. Genome Biol. 5, R80. doi: 10.1186/gb-2004-5-10-r80

Goldman, N., Chandler-Militello, D., Langevin, H. M., Nedergaard, M., and Takano, T. (2013). Purine receptor mediated actin cytoskeleton remodeling of human fibroblasts. Cell Calcium 53, 297-301. doi: 10.1016/j.ceca.2013.01.004

Gould, L., and Kendall, N. R. (2011). Role of the rumen in copper and thiomolybdate absorption. Nutr. Res. Rev. 24, 176-182. doi: 10.1017/S0954422411000059

Gould, T. W., and Oppenheim, R. W. (2011). Motor neuron trophic factors: therapeutic use in ALS? Brain Res. Rev. 67, 1-39. doi: 10.1016/j.brainresrev.2010. 10.003

Guipponi, M., Li, Q. X., Hyde, L., Beissbarth, T., Smyth, G. K., Masters, C. L., et al. (2010). SAGE analysis of genes differentially expressed in presymptomatic TgSOD1G93A transgenic mice identified cellular processes involved in early stage of ALS pathology. J. Mol. Neurosci. 41, 172-182. doi: 10.1007/s12031-0099317-1

Gundlach, A. L., Grabara, C. S., Johnston, G. A., and Harper, P. A. (1990). Receptor alterations associated with spinal motoneuron degeneration in bovine Akabane disease. Ann. Neurol. 27, 513-519. doi: 10.1002/ana.410270510

Gurney, M. E. (1994). Transgenic-mouse model of amyotrophic lateral sclerosis. N. Engl. J. Med. 331, 1721-1722. doi: 10.1056/NEJM199412223312516

Hadano, S., Hand, C. K., Osuga, H., Yanagisawa, Y., Otomo, A., Devon, R. S., et al. (2001). A gene encoding a putative GTPase regulator is mutated in familial amyotrophic lateral sclerosis 2. Nat. Genet. 29, 166-173. doi: 10.1038/ng1001-166

Hadano, S., Otomo, A., Kunita, R., Suzuki-Utsunomiya, K., Akatsuka, A., Koike, M., et al. (2010). Loss of ALS2/Alsin exacerbates motor dysfunction in a SOD1expressing mouse ALS model by disturbing endolysosomal trafficking. PLoS ONE 5:e9805. doi: 10.1371/journal.pone.0009805

Hafezparast, M., Klocke, R., Ruhrberg, C., Marquardt, A., Ahmad-Annuar, A., Bowen, S., et al. (2003). Mutations in dynein link motor neuron degeneration to defects in retrograde transport. Science 300, 808-812. doi: $10.1126 /$ science. 1083129

Hanyu, N., Oguchi, K., Yanagisawa, N., and Tsukagoshi, H. (1982). Degeneration and regeneration of ventral root motor fibers in amyotrophic lateral sclerosis. Morphometric studies of cervical ventral roots. J. Neurol. Sci. 55, 99-115. doi: 10.1016/0022-510X(82)90173-3

Heads, T., Pollock, M., Robertson, A., Sutherland, W. H., and Allpress, S. (1991). Sensory nerve pathology in amyotrophic lateral sclerosis. Acta Neuropathol. 82, 316-320.

Hensley, K., Floyd, R. A., Gordon, B., Mou, S., Pye, Q. N., Stewart, C., et al. (2002). Temporal patterns of cytokine and apoptosis-related gene expression in spinal cords of the G93A-SOD1 mouse model of amyotrophic lateral sclerosis. J. Neurochem. 82, 365-374. doi: 10.1046/j.1471-4159.2002.00968.x

Herzenberg, L. A., Tung, J., Moore, W. A., and Parks, D. R. (2006). Interpreting flow cytometry data: a guide for the perplexed. Nat. Immunol. 7, 681-685. doi: 10.1038/ni0706-681

Huang Da, W., Sherman, B. T., Stephens, R., Baseler, M. W., Lane, H. C., and Lempicki, R. A. (2008). DAVID gene ID conversion tool. Bioinformation 2, 428-430. doi: 10.6026/97320630002428

Hulsen, T., De Vlieg, J., and Alkema, W. (2008). BioVenn - a web application for the comparison and visualization of biological lists using area-proportional Venn diagrams. BMC Genomics 9:488. doi: 10.1186/1471-2164-9-488

Husseman, J. W., Nochlin, D., and Vincent, I. (2000). Mitotic activation: a convergent mechanism for a cohort of neurodegenerative diseases. Neurobiol. Aging 21, 815-828. doi: 10.1016/S0197-4580(00)00221-9

Ito, M., Swanson, B., Sussman, M. A., Kedes, L., and Lyons, G. (1995). Cloning of tropomodulin cDNA and localization of gene transcripts 
during mouse embryogenesis. Dev. Biol. 167, 317-328. doi: 10.1006/dbio. 1995.1026

Jablonka, S., Wiese, S., and Sendtner, M. (2004). Axonal defects in mouse models of motoneuron disease. J. Neurobiol. 58, 272-286. doi: 10.1002/neu.10313

Jiang, Y. M., Yamamoto, M., Kobayashi, Y., Yoshihara, T., Liang, Y., Terao, S., et al. (2005). Gene expression profile of spinal motor neurons in sporadic amyotrophic lateral sclerosis. Ann. Neurol. 57, 236-251. doi: 10.1002/ana.20379

Jiang, Y. M., Yamamoto, M., Tanaka, F., Ishigaki, S., Katsuno, M., Adachi, H., et al. (2007). Gene expressions specifically detected in motor neurons (dynactin 1, early growth response 3, acetyl-CoA transporter, death receptor 5 , and cyclin C) differentially correlate to pathologic markers in sporadic amyotrophic lateral sclerosis. J. Neuropathol. Exp. Neurol. 66, 617-627. doi: 10.1097/nen.0b013e318093ece3

Keller, A. F., Gravel, M., and Kriz, J. (2009). Live imaging of amyotrophic lateral sclerosis pathogenesis: disease onset is characterized by marked induction of GFAP in Schwann cells. Glia 57, 1130-1142. doi: 10.1002/glia.20836

Kiernan, M. C., Vucic, S., Cheah, B. C., Turner, M. R., Eisen, A., Hardiman, O., et al. (2011). Amyotrophic lateral sclerosis. Lancet 377, 942-955. doi: 10.1016/S01406736(10)

Kiryu-Seo, S., and Kiyama, H. (2011). The nuclear events guiding successful nerve regeneration. Front. Mol. Neurosci. 4:53. doi: 10.3389/fnmol.2011.00053

Koh, S. H., Roh, H., Lee, S. M., Kim, H. J., Kim, M., Lee, K. W., et al. (2005). Phosphatidylinositol 3-kinase activator reduces motor neuronal cell death induced by G93A or A4V mutant SOD1 gene. Toxicology 213, 45-55. doi: 10.1016/j.tox.2005.05.009

Korner, S., Boselt, S., Thau, N., Rath, K. J., Dengler, R., and Petri, S. (2013). Differential sirtuin expression patterns in amyotrophic lateral sclerosis (ALS) postmortem tissue: neuroprotective or neurotoxic properties of sirtuins in ALS? Neurodegener. Dis. 11, 141-152. doi: 10.1159/000338048

Kudo, L. C., Parfenova, L., Vi, N., Lau, K., Pomakian, J., Valdmanis, P., et al. (2010). Integrative gene-tissue microarray-based approach for identification of human disease biomarkers: application to amyotrophic lateral sclerosis. Hum. Mol. Genet. 19, 3233-3253. doi: 10.1093/hmg/ddq232

Kuzma-Kozakiewicz, M., Chudy, A., Gajewska, B., Dziewulska, D., Usarek, E., and Baranczyk-Kuzma, A. (2013). Kinesin expression in the central nervous system of humans and transgenic hSOD1G93A mice with amyotrophic lateral sclerosis. Neurodegener. Dis. 12, 71-80. doi: 10.1159/000339529

Lai, C., Xie, C., Shim, H., Chandran, J., Howell, B. W., and Cai, H. (2009). Regulation of endosomal motility and degradation by amyotrophic lateral sclerosis 2/alsin. Mol. Brain 2, 23. doi: 10.1186/1756-6606-2-23

Levine, J. B., Kong, J., Nadler, M., and Xu, Z. (1999). Astrocytes interact intimately with degenerating motor neurons in mouse amyotrophic lateral sclerosis (ALS). Glia 28, 215-224. doi: 10.1002/(SICI) 1098-1136(199912)28:3<215::AIDGLIA5 > 3.0.CO;2-C

Liu, J. X., Brannstrom, T., Andersen, P. M., and Pedrosa-Domellof, F. (2013). Distinct changes in synaptic protein composition at neuromuscular junctions of extraocular muscles versus limb muscles of ALS donors. PLoS ONE 8:e57473. doi: 10.1371/journal.pone.0057473

Lobsiger, C. S., Boillee, S., and Cleveland, D. W. (2007). Toxicity from different SOD1 mutants dysregulates the complement system and the neuronal regenerative response in ALS motor neurons. Proc. Natl. Acad. Sci. U.S.A. 104, 7319-7326. doi: 10.1073/pnas.0702230104

Lyons, D. A., Naylor, S. G., Scholze, A., and Talbot, W. S. (2009). Kif1b is essential for mRNA localization in oligodendrocytes and development of myelinated axons. Nat. Genet. 41, 854-858. doi: 10.1038/ng.376

Magrane, J., and Manfredi, G. (2009). Mitochondrial function, morphology, and axonal transport in amyotrophic lateral sclerosis. Antioxid. Redox Signal. 11, 1615-1626. doi: 10.1089/ARS.2009.2604

Malaspina, A., Ngoh, S. F., Ward, R. E., Hall, J. C., Tai, F. W., Yip, P. K., et al. (2010). Activation transcription factor-3 activation and the development of spinal cord degeneration in a rat model of amyotrophic lateral sclerosis. Neuroscience 169 , 812-827. doi: 10.1016/j.neuroscience.2010.04.053

Malmqvist, T., Anthony, K., and Gallo, J. M. (2014). Tau mRNA is present in axonal RNA granules and is associated with elongation factor 1A. Brain Res. doi: 10.1016/j.brainres.2013.12.033. [Epub ahead of print].

McGeer, P. L., and McGeer, E. G. (2002). Inflammatory processes in amyotrophic lateral sclerosis. Muscle Nerve 26, 459-470. doi: 10.1002/mus.10191

Monk, K. R., and Talbot, W. S. (2009). Genetic dissection of myelinated axons in zebrafish. Curr. Opin. Neurobiol. 19, 486-490. doi: 10.1016/j.conb.2009.08.006
Morfini, G. A., Bosco, D. A., Brown, H., Gatto, R., Kaminska, A., Song, Y., et al. (2013). Inhibition of fast axonal transport by pathogenic SOD1 involves activation of p38 MAP kinase. PLoS ONE 8:e65235. doi: 10.1371/journal.pone.0065235

Nangaku, M., Sato-Yoshitake, R., Okada, Y., Noda, Y., Takemura, R., Yamazaki, H., et al. (1994). KIF1B, a novel microtubule plus end-directed monomeric motor protein for transport of mitochondria. Cell 79, 1209-1220. doi: 10.1016/00928674(94)90012-4

Niapour, A., Karamali, F., Karbalaie, K., Kiani, A., Mardani, M., Nasr-Esfahani, M. H., et al. (2010). Novel method to obtain highly enriched cultures of adult rat Schwann cells. Biotechnol. Lett. 32, 781-786. doi: 10.1007/s10529-010-0230-z

Niewiadomska, G., Mietelska-Porowska, A., and Mazurkiewicz, M. (2011). The cholinergic system, nerve growth factor and the cytoskeleton. Behav. Brain Res. 221, 515-526. doi: 10.1016/j.bbr.2010.02.024

Nishimura, A. L., Mitne-Neto, M., Silva, H. C., Richieri-Costa, A., Middleton, S., Cascio, D., et al. (2004). A mutation in the vesicle-trafficking protein VAPB causes late-onset spinal muscular atrophy and amyotrophic lateral sclerosis. Am. J. Hum. Genet. 75, 822-831. doi: 10.1086/425287

Nishimura, Y., Hayashi, M., Inada, H., and Tanaka, T. (1999). Molecular cloning and characterization of mammalian homologues of vesicle-associated membrane protein-associated (VAMP-associated) proteins. Biochem. Biophys. Res. Commun. 254, 21-26. doi: 10.1006/bbrc.1998.9876

Offen, D., Barhum, Y., Melamed, E., Embacher, N., Schindler, C., and Ransmayr, G. (2009). Spinal cord mRNA profile in patients with ALS: comparison with transgenic mice expressing the human SOD-1 mutant. J. Mol. Neurosci. 38, 85-93. doi: 10.1007/s12031-007-9004-z

Okada, Y., Yamazaki, H., Sekine-Aizawa, Y., and Hirokawa, N. (1995). The neuronspecific kinesin superfamily protein KIF1A is a unique monomeric motor for anterograde axonal transport of synaptic vesicle precursors. Cell 81, 769-780. doi: 10.1016/0092-8674(95)90538-3

Olsen, M. K., Roberds, S. L., Ellerbrock, B. R., Fleck, T. J., McKinley, D. K., and Gurney, M. E. (2001). Disease mechanisms revealed by transcription profiling in SOD1-G93A transgenic mouse spinal cord. Ann. Neurol. 50, 730-740. doi: 10.1002/ana.1252

Oudega, M., Xu, X. M., Guenard, V., Kleitman, N., and Bunge, M. B. (1997). A combination of insulin-like growth factor-I and platelet-derived growth factor enhances myelination but diminishes axonal regeneration into Schwann cell grafts in the adult rat spinal cord. Glia 19, 247-258. doi: 10.1002/(SICI)10981136(199703) 19:3<247::AID-GLIA7>3.0.CO;2-W

Pantelidou, M., Zographos, S. E., Lederer, C. W., Kyriakides, T., Pfaffl, M. W., and Santama, N. (2007). Differential expression of molecular motors in the motor cortex of sporadic ALS. Neurobiol. Dis. 26, 577-589. doi: 10.1016/j.nbd.2007.02.005

Parkhouse, W. S., Cunningham, L., McFee, I., Miller, J. M., Whitney, D., Pelech, S. L., et al. (2008). Neuromuscular dysfunction in the mutant superoxide dismutase mouse model of amyotrophic lateral sclerosis. Amyotroph. Lateral Scler. 9, 24-34. doi: 10.1080/17482960701725646

Pasinelli, P., and Brown, R. H. (2006). Molecular biology of amyotrophic lateral sclerosis: insights from genetics. Nat. Rev. Neurosci. 7, 710-723. doi: 10.1038/nrn1971

Perrie, W. T., Lee, G. T., Curtis, E. M., Sparke, J., Buller, J. R., and Rossi, M. L. (1993). Changes in the myelinated axons of femoral nerve in amyotrophic lateral sclerosis. J. Neural Transm. Suppl. 39, 223-233. doi: 10.1155/2011/718987

Perrin, F. E., Boisset, G., Docquier, M., Schaad, O., Descombes, P., and Kato, A. C. (2005). No widespread induction of cell death genes occurs in pure motoneurons in an amyotrophic lateral sclerosis mouse model. Hum. Mol. Genet. 14, 3309-3320. doi: 10.1093/hmg/ddi357

Pradat, P. F., Dubourg, O., De Tapia, M., Di Scala, F., Dupuis, L., Lenglet, T., et al. (2012). Muscle gene expression is a marker of amyotrophic lateral sclerosis severity. Neurodegener. Dis. 9, 38-52. doi: 10.1159/000329723

Rothstein, J. D. (2009). Current hypotheses for the underlying biology of amyotrophic lateral sclerosis. Ann. Neurol. 65(Suppl. 1), S3-S9. doi: 10.1002/ana. 21543

Schwab, J. M., Frei, E., Klusman, I., Schnell, L., Schwab, M. E., and Schluesener, H. J. (2001). AIF-1 expression defines a proliferating and alert microglial/macrophage phenotype following spinal cord injury in rats. J. Neuroimmunol. 119, 214-222. doi: 10.1016/S0165-5728(01)00375-7

Scorisa, J. M., Duobles, T., Oliveira, G. P., Maximino, J. R., and Chadi, G. (2010). The review of the methods to obtain non-neuronal cells to study glial influence 
on Amyotrophic Lateral Sclerosis pathophysiology at molecular level in vitro. Acta Cir. Bras. 25, 281-289. doi: 10.1590/S0102-86502010000300011

Shapiro, H. M. (2005). Practical Flow Cytometry. New York, NY: Wiley-Liss.

Shaw, C. E., Al-Chalabi, A., and Leigh, N. (2001). Progress in the pathogenesis of amyotrophic lateral sclerosis. Curr. Neurol. Neurosci. Rep. 1, 69-76. doi: 10.1007/s11910-001-0078-7

Smyth, G. K. (2005). "Limma: linear models for microarray data," in Bioinformatics and Computational Biology Solutions using $R$ and Bioconductor, eds V. C. R. Gentleman, S. Dudoit, R. Irizarry, and W. Huber (New York, NY: Springer), 397-420.

Spadoni, O., Crestini, A., Piscopo, P., Malvezzi-Campeggi, L., Carunchio, I., Pieri, M., et al. (2009). Gene expression profiles of APP and BACE1 in Tg SOD1G93A cortical cells. Cell. Mol. Neurobiol. 29, 635-641. doi: 10.1007/s10571-009-9356-8

Strey, C. W., Spellman, D., Stieber, A., Gonatas, J. O., Wang, X., Lambris, J. D., et al. (2004). Dysregulation of stathmin, a microtubule-destabilizing protein, and upregulation of Hsp25, Hsp27, and the antioxidant peroxiredoxin 6 in a mouse model of familial amyotrophic lateral sclerosis. Am. J. Pathol. 165, 1701-1718. doi: 10.1016/S0002-9440(10)63426-8

Strom, A. L., Shi, P., Zhang, F., Gal, J., Kilty, R., Hayward, L. J., et al. (2008). Interaction of amyotrophic lateral sclerosis (ALS)-related mutant copper-zinc superoxide dismutase with the dynein-dynactin complex contributes to inclusion formation. J. Biol. Chem. 283, 22795-22805. doi: 10.1074/jbc.M800276200

Sunico, C. R., Dominguez, G., Garcia-Verdugo, J. M., Osta, R., Montero, F., and Moreno-Lopez, B. (2011). Reduction in the motoneuron inhibitory/excitatory synaptic ratio in an early-symptomatic mouse model of amyotrophic lateral sclerosis. Brain Pathol. 21, 1-15. doi: 10.1111/j.1750-3639.2010.00417.x

Taes, I., Timmers, M., Hersmus, N., Bento-Abreu, A., Van Den Bosch, L., Van Damme, P., et al. (2013). Hdac6 deletion delays disease progression in the SOD1G93A mouse model of ALS. Hum. Mol. Genet. 22, 1783-1790. doi: $10.1093 / \mathrm{hmg} / \mathrm{ddt} 028$

Tanaka, F., Ikenaka, K., Yamamoto, M., and Sobue, G. (2012). Neuropathology and omics in motor neuron diseases. Neuropathology 32, 458-462. doi: 10.1111/j.1440-1789.2011.01281.x

Tanaka, F., Niwa, J., Ishigaki, S., Katsuno, M., Waza, M., Yamamoto, M., et al. (2006). Gene expression profiling toward understanding of ALS pathogenesis. Ann. N.Y. Acad. Sci. 1086, 1-10. doi: 10.1196/annals.1377.011

Ticozzi, N., Ratti, A., and Silani, V. (2010). Protein aggregation and defective RNA metabolism as mechanisms for motor neuron damage. CNS Neurol. Disord. Drug Targets 9, 285-296. doi: 10.2174/187152710791292585

Tripathi, V. B., and Al-Chalabi, A. (2008). Molecular insights and therapeutic targets in amyotrophic lateral sclerosis. CNS Neurol. Disord. Drug Targets 7, 11-19. doi: $10.2174 / 187152708783885110$

Usuki, S., Kamitani, T., Matsuo, Y., and Yu, R. K. (2012). Pathobiochemical effect of acylated steryl-beta-glucoside on aggregation and cytotoxicity of alphasynuclein. Neurochem. Res. 37, 1261-1266. doi: 10.1007/s11064-011-0662-4

Van Gelder, R. N., Von Zastrow, M. E., Yool, A., Dement, W. C., Barchas, J. D., and Eberwine, J. H. (1990). Amplified RNA synthesized from limited quantities of heterogeneous cDNA. Proc. Natl. Acad. Sci. U.S.A. 87, 1663-1667.

Vargas, M. R., Pehar, M., Diaz-Amarilla, P. J., Beckman, J. S., and Barbeito, L. (2008). Transcriptional profile of primary astrocytes expressing ALS-linked mutant SOD1. J Neurosci. Res. 86, 3515-3525. doi: 10.1002/jnr.21797
Vinsant, S., Mansfield, C., Jimenez-Moreno, R., Del Gaizo Moore, V., Yoshikawa, M., Hampton, T. G., et al. (2013). Characterization of early pathogenesis in the SOD1(G93A) mouse model of ALS: part II, results and discussion. Brain Behav. 3, 431-457. doi: 10.1002/brb3.142

Wang, Y., Kaiser, C. E., Frett, B., and Li, H. Y. (2013). Targeting mutant KRAS for anticancer therapeutics: a review of novel small molecule modulators. J. Med. Chem. 56, 5219-5230. doi: 10.1021/jm3017706

Warita, H., Itoyama, Y., and Abe, K. (1999). Selective impairment of fast anterograde axonal transport in the peripheral nerves of asymptomatic transgenic mice with a G93A mutant SOD1 gene. Brain Res. 819, 120-131. doi: 10.1016/S0006-8993(98)01351-1

White, F. V., Ceccarini, C., Georgieff, I., Matthieu, J. M., and Costantino-Ceccarini, E. (1983). Growth properties and biochemical characterization of mouse Schwann cells cultured in vitro. Exp. Cell. Res. 148, 183-194. doi: 10.1016/00144827(83)90198-2

Williamson, T. L., and Cleveland, D. W. (1999). Slowing of axonal transport is a very early event in the toxicity of ALS-linked SOD1 mutants to motor neurons. Nat. Neurosci. 2, 50-56. doi: 10.1038/4553

Xiao, S., McLean, J., and Robertson, J. (2006). Neuronal intermediate filaments and ALS: a new look at an old question. Biochim. Biophys. Acta 1762, 1001-1012. doi: 10.1016/j.bbadis.2006.09.003

Yamanaka, K., Chun, S. J., Boillee, S., Fujimori-Tonou, N., Yamashita, H., Gutmann, D. H., et al. (2008). Astrocytes as determinants of disease progression in inherited amyotrophic lateral sclerosis. Nat. Neurosci. 11, 251-253. doi: 10.1038/nn2047

Yang, Y., Hentati, A., Deng, H. X., Dabbagh, O., Sasaki, T., Hirano, M., et al. (2001). The gene encoding alsin, a protein with three guanine-nucleotide exchange factor domains, is mutated in a form of recessive amyotrophic lateral sclerosis. Nat. Genet. 29, 160-165. doi: 10.1038/ng1001-160

Yoshihara, T., Ishigaki, S., Yamamoto, M., Liang, Y., Niwa, J., Takeuchi, H., et al. (2002). Differential expression of inflammation- and apoptosis-related genes in spinal cords of a mutant SOD1 transgenic mouse model of familial amyotrophic lateral sclerosis. J. Neurochem. 80, 158-167. doi: 10.1046/j.00223042.2001.00683.x

Conflict of Interest Statement: The authors declare that the research was conducted in the absence of any commercial or financial relationships that could be construed as a potential conflict of interest.

Received: 23 January 2014; accepted: 08 May 2014; published online: 26 May 2014. Citation: Maximino JR, de Oliveira GP, Alves CJ and Chadi G (2014) Deregulated expression of cytoskeleton related genes in the spinal cord and sciatic nerve of presymptomatic SOD1 ${ }^{\mathrm{G} 93 \mathrm{~A}}$ Amyotrophic Lateral Sclerosis mouse model. Front. Cell. Neurosci. 8:148. doi: $10.3389 /$ fncel.2014.00148

This article was submitted to the journal Frontiers in Cellular Neuroscience.

Copyright (c) 2014 Maximino, de Oliveira, Alves and Chadi. This is an open-access article distributed under the terms of the Creative Commons Attribution License (CC BY). The use, distribution or reproduction in other forums is permitted, provided the original author(s) or licensor are credited and that the original publication in this journal is cited, in accordance with accepted academic practice. No use, distribution or reproduction is permitted which does not comply with these terms. 